\begin{tabular}{|l||}
\hline Athens Journal of Tourism \\
Volume 7, Issue 2, June 2020 \\
Aroticles \\
Front Pages \\
PETER JONES E DAPHNE COMFORT \\
The COVID-19 Crisis, Tourism and Sustainable Development \\
GREGORY T. PAPANIKOS \\
The Impact of the Covid-19 Pandemic on Greek Tourism \\
ELMIRA DJAFAROVA \& KRISTINA KRAMER \\
SANDY C. CHEN \\
Understanding the Evolving Roles of Outbound Education Tourism \\
in China: Past, Present, and Future
\end{tabular}




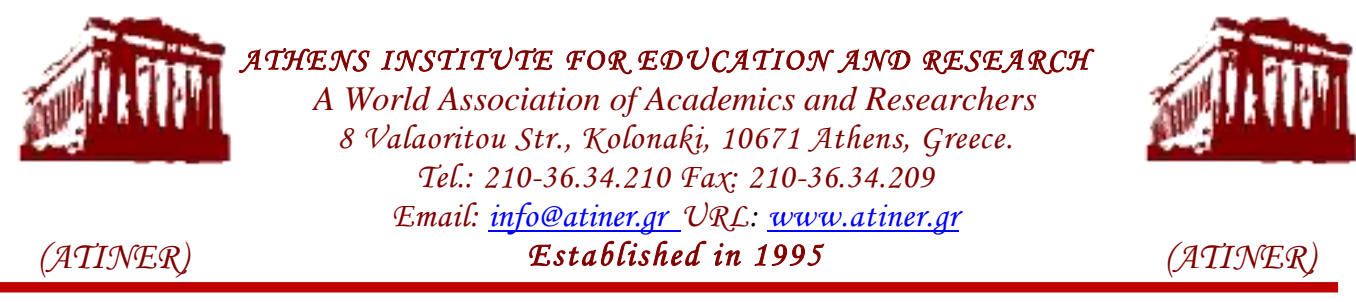

\section{Mission}

ATINER is an Athens-based World Association of Academics and Researchers based in Athens. ATINER is an independent and non-profit Association with a Mission to become a forum where Academics and Researchers from all over the world can meet in Athens, exchange ideas on their research and discuss future developments in their disciplines, as well as engage with professionals from other fields. Athens was chosen because of its long history of academic gatherings, which go back thousands of years to Plato's Academy and Aristotle's Lyceum. Both these historic places are within walking distance from ATINER's downtown offices. Since antiquity, Athens was an open city. In the words of Pericles, Athens"... is open to the world, we never expel a foreigner from learning or seeing". ("Pericles' Funeral Oration", in Thucydides, The History of the Peloponnesian War). It is ATINER's mission to revive the glory of Ancient Athens by inviting the World Academic Community to the city, to learn from each other in an environment of freedom and respect for other people's opinions and beliefs. After all, the free expression of one's opinion formed the basis for the development of democracy, and Athens was its cradle. As it turned out, the Golden Age of Athens was in fact, the Golden Age of the Western Civilization. Education and (Re)searching for the 'truth' are the pillars of any free (democratic) society. This is the reason why Education and Research are the two core words in ATINER's name. 
The Athens Journal of Tourism

ISSN NUMBER: 2241-8148- DOI: 10.30958/ajt

Volume 7, Issue 2, June 2020

Download the Entire Issue ( $\underline{\mathrm{PDF}})$

Front Pages $\quad$ i-viii

The COVID-19 Crisis, Tourism and Sustainable $\quad 75$

Development

Peter Jones \& Daphne Comfort

The Impact of the Covid-19 Pandemic on Greek

87

Tourism

Gregory T. Papanikos

Understanding the Evolving Roles of Outbound

Education Tourism in China: Past, Present, and Future

Sandy C. Chen

Is YouTube Advertising Effective: Context of Travel

Industry?

Elmira Djafarova \& Kristina Kramer 


\section{Athens Journal of Tourism Editorial and Reviewers' Board}

Editors

- Dr. Peter Jones, Professor of Management, University of Gloucestershire, U.K.

- Dr. Valia Kasimati, Head, Tourism, Leisure \& Recreation Unit, ATINER \& Researcher, Department of Economic Analysis \& Research, Central Bank of Greece, Greece.

\section{Editorial Board}

- $\quad$ Dr. Francesco Favia, Academic Member, ATINER \& President, Apuliae Open University, Italy.

- Dr. Mary L. Tanke, Distinguished Professor, Chaplin School of Hospitality \& Tourism Management Biscayne Bay Campus, Florida International University, USA.

- Dr. Cláudia Ribeiro de Almeida, Adjunct Professor, University of Algarve, Portugal.

- Dr. Cinthia Rolim de Albuquerque Meneguel, Teacher and Researcher, Federal Institute of Education, Science and Technology of Sao Paolo, Brazil.

- Dr. Kevin Mearns, Professor, Department of Environmental Sciences, UNISA, South Africa.

- Dr. Ige Pirnar, Professor and Member, University Executive Board, Department of Business Administration, Yasar University, Faculty of Economics and Administrative Studies, Turkey.

- Dr. Henry Thompson, Professor Emeritus, Department of Economics, Auburn University, USA.

- $\quad$ Dr. Andrew Yiannakis, Professor, University of New Mexico, USA.

- $\quad$ Dr. Mzobanzi Erasmus Mnguni, Head, Department of Hospitality and Tourism, Durban University of Technology, South Africa.

- $\quad$ Dr. Kathryn Velander, Academic Member, ATINER \& Reader, Edinburgh Napier University, UK.

- Dr. Moustafa Ahmed El-Sayed Ahmed Mekawy, Associate Professor, University of Sadat City, Egypt.

- Dr. Graham Busby, Associate Professor, Faculty of Business, School of Tourism and Hospitality, Plymouth University, UK.

- Dr. Phylis Floyd, Academic Member, ATINER \& Associate Professor, Department of Art, Art History \& Design, Michigan State University, USA.

- $\quad$ Dr. Michael Scantlebury, Academic Member, ATINER \& Associate Professor, Grand Valley State University, USA.

- $\quad$ Dr. Rodanthi Tzanelli, Academic Member, ATINER \& Associate Professor of Cultural Sociology, School of Sociology \& Social Policy, University of Leeds, U.K.

- Dr. Essam Abdel Salam Gouda, Academic Member, ATINER \& Assistant Professor, College of Engineering, Al-Azhar University, Egypt.

- $\quad$ Dr. Tarek Abdelsalam, Assistant Professor, Department of Architecture, University of Modern Sciences and Arts (MSA), Egypt.

- Dr. Aytug Arslan, Assistant Professor, İzmir Katip Çelebi University, Tourism Faculty, Department of Tourist Guidance, Turkey.

- $\quad$ Dr. Sonia Khan, Assistant Professor in Tourism, H.P. University, Shimla, India.

- Dr. Ozlem Karakul, Associate Professor, Faculty of Arts, Selçuk University, Turkey.

- Dr. Per Ake Nilsson, Assistant Professor in Tourism Science, Mid Sweden University, Sweden.

- $\quad$ Dr. Roselyne N. Okech, Assistant Professor, Memorial University of Newfoundland, Canada.

- Dr. Marianna Strzelecka, Assistant Professor, Department of Hospitality and Tourism Management, College of Merchandising, Hospitality and Tourism, University of North Texas, USA.

- Dr. Maria Belen Kraser, Teacher in Seminary Gestion of natural resources and environment, and Didactic of Geography, Universidad Nacional del Sur- UNS, Brazil.

- Dr. Azila Azmi, Senior Lecturer, Faculty of Hotel and Tourism Management, University of Technology MARA (Pulau Pinang), Malaysia.

- Dr. Lois Ann Burgess, Lecturer, School of Management and Marketing, University of Wollongong, Australia.

- Dr. Joseph Mensah-Ansah, Lecturer, GIMPA Business School, Ghana.

- $\quad$ Ms. Suchitra Wagle, Academic Member, ATINER \& PhD and Researcher, Indian Institute of Technology, India.

- Ms. Hatice Ozgul Ozhisar, Academic Member, ATINER \& Ph.D. Candidate, Middle East Technical University, \& Expert, Ministry of Tourism, Turkey.

- Vice President of Publications: Dr Zoe Boutsioli

- General Managing Editor of all ATINER's Publications: Ms. Afrodete Papanikou

- ICT Managing Editor of all ATINER's Publications: Mr. Kostas Spyropoulos

- Managing Editor of this Journal: Ms. Eirini Lentzou (bio) 


\section{President's Message}

All ATINER's publications including its e-journals are open access without any costs (submission, processing, publishing, open access paid by authors, open access paid by readers etc.) and is independent of presentations at any of the many small events (conferences, symposiums, forums, colloquiums, courses, roundtable discussions) organized by ATINER throughout the year and entail significant costs of participating. The intellectual property rights of the submitting papers remain with the author. Before you submit, please make sure your paper meets the basic academic standards, which includes proper English. Some articles will be selected from the numerous papers that have been presented at the various annual international academic conferences organized by the different divisions and units of the Athens Institute for Education and Research. The plethora of papers presented every year will enable the editorial board of each journal to select the best, and in so doing produce a top-quality academic journal. In addition to papers presented, ATINER will encourage the independent submission of papers to be evaluated for publication.

The current issue is the second of the seventh volume of the Athens Journal of Tourism, published by the Tourism, Leisure \& Recreation Unit of ATINER.

Gregory T. Papanikos

President

ATINER 


\section{Athens Institute for Education and Research}

\section{A World Association of Academics and Researchers}

\section{$14^{\text {th }}$ Annual International Conference on \\ Mediterranean Studies, 29-31 March \& 1 April 2021, Athens, Greece}

The Center for European \& Mediterranean Affairs organizes the $14^{\text {th }}$ Annual International Conference on Mediterranean Studies, 29-31 March \& 1 April 2021, Athens, Greece sponsored by the Athens Journal of Mediterranean Studies. The aim of the conference is to bring together academics and researchers from all areas of Mediterranean Studies, such as history, arts, archaeology, philosophy, culture, sociology, politics, international relations, economics, business, sports, environment and ecology, etc.You may participate as stream leader, presenter of one paper, chair a session or observer. Please submit a proposal using the form available (https:// www.atiner.gr/2021/FORM-MDT.doc).

Academic Members Responsible for the Conference

- Dr. Gregory T. Papanikos, President, ATINER \& Honorary Professor, University of Stirling, U.K.

- Dr. Steven Oberhelman, Professor of Classics, Holder of the George Sumey Jr Endowed Professorship of Liberal Arts, and Associate Dean, Texas A\&M University, USA, Vice President of International Programs, ATINER and Editor of the Athens Journal of History.

- Dr. Nicholas Pappas, Vice President of Academic Membership, ATINER \& Professor of History, Sam Houston University, USA.

- Dr. David Philip Wick, Director, Arts, Humanities and Education Division, ATINER \& Professor of History, Gordon College, USA.

- Dr. Yannis Stivachtis, Director, Center for European \& Mediterranean Affairs and Associate Professor, Jean Monnet Chair \& Director of International Studies Program, Virginia Tech - Virginia Polytechnic Institute \& State Universitv, USA.

\begin{tabular}{|c} 
Important Dates \\
\hline \hline - Abstract Submission: 31 August 2020 \\
- Acceptance of Abstract: 4 Weeks after Submission \\
- Submission of Paper: 1 March 2021 \\
\hline
\end{tabular}

\section{Conference Fees}

Conference fees vary from $400 €$ to $2000 €$

Details can be found at: https://www.atiner.gr/2019fees

\section{Social and Educational Program}

The Social Program Emphasizes the Educational Aspect of the Academic Meetings of Atiner.

- Greek Night Entertainment (This is the official dinner of the conference)

- Athens Sightseeing: Old and New-An Educational Urban Walk

- Social Dinner

- Mycenae Visit

- Exploration of the Aegean Islands

- Delphi Visit

- Ancient Corinth and Cape Sounion 


\section{Athens Institute for Education and Research}

A World Association of Academics and Researchers

\section{$16^{\text {th }}$ Annual International Conference on Tourism \\ 8-11 June 2020, Athens, Greece}

The Tourism, Leisure \& Recreation Unit of ATINER organizes its $\mathbf{1 6}^{\text {th }}$ Annual International Conference on Tourism, 8-11 June 2020, Athens, Greece sponsored by the Athens Journal of Tourism. The aim of the conference is to bring together academics and researchers from all areas of Tourism. You may participate as stream leader, presenter of one paper, chair a session or observer. Please submit a proposal using the form available (https://www.atiner.gr/2020/FORM-TOU.doc).

- Abstract Submission: 25 May 2020

\section{Important Dates}

- Acceptance of Abstract: 4 Weeks after Submission

- Submission of Paper: 11 May 2020

\section{Academic Member Responsible for the Conference}

- Dr. Valia Kasimati, Head, Tourism, Leisure \& Recreation Unit, ATINER \& Researcher, Department of Economic Analysis \& Research, Central Bank of Greece, Greece.

- Dr. Peter Jones, Co-Editor, Athens Journal of Tourism \& Professor of Management, University of Gloucestershire, UK.

\section{Social and Educational Program}

The Social Program Emphasizes the Educational Aspect of the Academic Meetings of Atiner.

- Greek Night Entertainment (This is the official dinner of the conference)

- Athens Sightseeing: Old and New-An Educational Urban Walk

- Social Dinner

- Mycenae Visit

- Exploration of the Aegean Islands

- Delphi Visit

- Ancient Corinth and Cape Sounion

More information can be found here: https://www.atiner.gr/social-program

\section{Conference Fees}

Conference fees vary from $400 €$ to $2000 €$

Details can be found at: https://www.atiner.gr/2019fees 



\title{
The COVID-19 Crisis, Tourism and Sustainable Development
}

\author{
By Peter Jones ${ }^{*} \&$ Daphne Comfort ${ }^{ \pm}$
}

\begin{abstract}
This paper explores some of the relationships between tourism and sustainable development through the lens of the COVID-19 crisis. The paper provides an outline of the COVID-19 crisis, and explores some of the relationships between tourism and sustainable development as illuminated by the COVID-19 crisis. The paper suggests that the COVID-19 crisis has not only posed a range of major challenges for the tourist industry but that it has also signaled some environmental changes that may be central to the transition to a more sustainable future, highlighted some of the inherent contradictions and complexities within the concept of sustainable development, and suggested some radical solutions to the challenges of sustainability. This is not an empirical paper, rather it rehearses some of the arguments about the relationships between the tourism industry and sustainability and draws on the views and opinions of a number of authorities on sustainable development within the industry. As such, the paper offers an accessible review of some of the relationships between tourism and sustainable development at a very testing time for the industry.
\end{abstract}

Keywords: COVID-19, crisis, tourism, sustainable development, corporate sustainability

\section{Introduction}

COVID-19 has been described by Kristalina Georgieva, Managing Director of the International Monetary Fund, as "a crisis like no other" (World Economic Forum 2020) and it certainly had had a devastating impact on both the global economy and on sectoral economies. Segal (2020), for example, writing under the banner of the Centre for Strategic and International Studies, claimed "at the sectoral level, tourism and travel-related industries will be among the hardest hit as authorities encourage social distancing and consumers to stay indoors." The United Nations World Tourism Organization (UNWTO) (2020) reported that "the worldwide outbreak of COVID-19 has brought the world to a standstill," and claimed that "tourism has been the worst affected of all major economic sectors." More specifically, Zurab Pololikashvili, Secretary-General of the UNWTO (2020) has argued "the sudden and unexpected fall in tourism demand caused by COVID19 places millions of jobs and livelihoods at risk while at the same time jeopardising the advances made in sustainable development and equality over recent years."

\footnotetext{
*Principal Lecturer, Northumbria University, UK.

${ }^{ \pm}$Former Research Student, Newcastle Business School, Northumbria University, UK.
} 
The initial formal definition of sustainable development namely, "development that meets the needs of the present without compromising the ability of future generations to meet their own needs" (World Commission on Environment and Development 1987) is still widely used over three decades after it was framed. That said, the concept has been extended to more fully recognise its environmental, social and economic dimensions, to embrace equity across geographical space, as well as over time, to incorporate business imperatives as part of corporate sustainability strategies, and to encompass a wide range of human endeavours and environmental events.

More specifically, the concept of sustainable development has attracted attention from tourism scholars. Hall et al. (2015), for example, claimed that sustainable tourism "has been incorporated into the fabric of academic discourse in academic, business and governance terms." Ural (2015) suggested that "the magnitude of disaster/catastrophic risks has become a major topic of discussion for a sustainable tourism." That said, work in this genre has traditionally been focussed on national economies or local environments. de Sausmarez (2007), for example, writing under the banner "Crisis Management, Sustainability and Tourism," argued that "the damage to tourism caused by a crisis or disaster may not only have serious implications for a national economy but also threaten the livelihoods of many in the destination." However, the COVID-19 crisis has posed a wide range of major challenges for tourism throughout the world and it has taken the tourism industry into uncharted waters.

With these thoughts in mind this paper explores some of the relationships between tourism and sustainable development through the lens of the COVID-19 crisis. The paper describes the features of the COVID-19 crisis, outlines some of the environmental, economic and social and impacts of the crisis, examines the consequences of the crisis for corporate sustainability programmes in the tourism industry and explores some of the inherent contradictions within the concept of sustainable development highlighted by the crisis. This is not an empirical paper, rather it rehearses some of the arguments about the relationships between tourism and sustainable development and draws on the views and opinions of a number of authorities on sustainable development within the tourism industry. The paper was written in May 2020, while both the authors were in lockdown, and as such, to adopt a military metaphor, it offers a view from the battlefield, at a time when the tourism industry seemed under siege.

\section{The COVID-19 Crisis}

COVID-19 is an infectious disease caused by SARS-CoV-2, a newly discovered coronavirus. Coronaviruses are part of a large family of viruses that can affect birds and mammals, including humans. In recent years, this family of viruses has been responsible for several disease outbreaks around the world, including Severe Acute Respiratory Syndrome in 2002-2003 and the Middle East Respiratory Syndrome first reported in South Korea in 2012. COVID-19 primarily affects the lungs and airways leading to mainly respiratory symptoms, e.g., cough 
and shortness of breath, and fevers. The majority of people with COVID-19 experience mild symptoms of the disease and recover without requiring specialist treatment. However older people, and those with underlying medical problems such as cardiovascular disease, diabetes, chronic respiratory disease and those with a weakened immune system are more likely to develop serious illness and are at an increased risk of dying from the disease.

The disease can spread from person to person through small droplets from the nose or mouth which are spread when a person with COVID-19 coughs, sneezes or exhales. These droplets land on objects and surfaces around the person. Other people then catch COVID-19 by touching these objects or surfaces, then touching their eyes, nose or mouth. People can also catch COVID-19 if they breathe in droplets from a person with COVID-19 who coughs, sneezes or exhales droplets. Precise details of the origins and initial spread of COVID-19 are hard to confirm, but there is some agreement that the disease originated in a wholesale market in Wuhan, a city of some 11 million people, in Eastern China, and that some of the market traders may have contracted the disease following contact with animals at the market.

On 31 December 2019, China alerted the World Health Organisation to several cases of unusual pneumonia in Wuhan, and several of those infected, worked at one of the city's markets. Early in 2020 the disease spread rapidly, first to other regions of China, and eventually to the majority of the world's countries, and the World Health Organisation declared the global outbreak of COVID-19 a pandemic on 11 March 2020. Though the nature of the response to the crisis has varied from one country to another, all medical authorities and governments have struggled to combat COVID-19. Medical pressures included providing large numbers of bed spaces and specialist equipment to treat seriously ill patients, sufficient numbers of, and personal protection equipment for, medical staff, and adequate testing facilities. The policies adopted by many governments have centred on enforcing social distancing by strongly recommending restrictions on the movement of people, popularly described as lockdown, and instructing many businesses to close down, in an attempt to prevent the spread of the disease.

The COVID-19 crisis has certainly had a wide range of environmental, economic and social consequences and as such has had a major impact on sustainable development. At the same time, the crisis has identified the need to extend the scope of sustainable development. Here there is the issue of the role of sustainable development in preventing future pandemics, as such events, thankfully relatively rare as they are, have not been included in traditional approaches to sustainability. Di Marco et al. (2020) observed that "little attention has been paid to the interactions between environmental change and infectious disease emergence" and such interactions are "not customarily integrated into planning for sustainable development." More specifically, Di Marco et al. (2020) claimed that the emergence of diseases "is driven by anthropogenic changes such as deforestation and expansion of agricultural land (i.e. land-use change), intensification of livestock production, and increased hunting and trading of wildlife." Looking to the future, Di Marco et al. (2020) claimed that human health could be more effectively integrated within sustainable development planning but 
argued this required "a cross-disciplinary research approach," which would involve "socioeconomic change, pathogen dynamics, and biological and behavioral aspects of humans, wildlife, and livestock."

\section{Environmental, Economic and Social Impacts}

The relationship between tourism and sustainable development, as illuminated by the COVID-19 crisis, can be seen in a number of ways. Initially, a number of environmental improvements were identified including marked reductions in pollution levels and greenhouse gas emissions, following the closure of many power generation plants and factories, the dramatic fall in the volume of air travel and the restrictions on the movement of people in motor vehicles. However, such improvements will surely not be maintained if/when the economy recovers. Inger Anderson, Head of the United Nations Environment Programme, for example, was reported as arguing "we need to take on board the environmental signals and what they mean for our future and wellbeing because COVID-19 is by no means a silver lining for the environment," that "visible positive impacts-whether through improved air quality or reduced greenhouse gas emissions-are but temporary because they come on the back of tragic economic slowdown and human distress" (United Nations Department of Social and Economic Affairs 2020).

While the COVID-19 crisis has brought some general environmental gains, it has also had a devastating economic and social impact. Within Europe, for example, Neisdadt (2020), writing in April 2020 under the banner of the European Parliament Research Service, estimated that the tourism industry within the European Union was losing Euro 1 billion per month as a result of the COVID-19 crisis. More specifically, Neisdadt (2020) suggested that "the situation is particularly difficult in several European Union countries that are key tourist destinations, such as Italy, Spain and France." Overall, Statista (2020) estimated that 1.6 million jobs were at risk in the tourism sector in Germany due to the COVID-19 crisis, while the corresponding figures for Russia, Italy, Spain, France and Portugal were 1.1 million, 1 million, 0.8 million, 0.8 million and 0.3 million, respectively.

More widely, the United Nations Department of Economic and Social Affairs (2020), for example, reported on the impact of COVID-19 on the global tourism industry, noting that, "many tourism dependent countries rely heavily on tourist arrivals from a particular country-the United States, for example-as in the case of many Caribbean countries. These economies would experience sharp increases in unemployment rates affecting the livelihood of low-skilled workers and the more vulnerable segments of society that depend on income from tourism-related activities." In an assessment of the impact of the COVID-19 crisis on international tourism dated 24 March 2020, the UNWTO (2020) cautioned that given "the unparalleled and fast-evolving nature of the crisis, it is extremely challenging to estimate the impact of COVID-19 on international tourism" but estimated that "international tourist arrivals could decline by $20 \%$ to $30 \%$ in $2020 . "$ Further the UNWTO (2020) suggested that this would translate into a loss of US $\$ 300$ to $\$ 450$ 
billion in international tourism receipts. More pessimistically, in April 2020, the Organisation for Economic Cooperation and Development (OECD) (2020) estimated that the decline in international tourism in 2020 could be between $45 \%$ and $70 \%$, depending on when recovery begins to take place, and warned that the general economic decline due to the COVID-19 crisis will also delay recovery within the tourism industry.

OECD (2020) has argued that the COVID-19 crisis, is "first and foremost, a humanitarian crisis affecting people's lives" and that "this has very tangible impacts for the tourism sector, which is critical for many people, places and businesses." Further, OECD (2020) argued that tourism "directly supports numerous types of jobs and businesses and underpins many local communities," that it is "a leading job creator, and in normal circumstances can help provide diverse employment opportunities for many low skilled immigrants, women, students and older workers" particularly "in remote, rural, coastal and other often economically fragile locations where alternative opportunities may be limited."

The COVID-19 crisis has clearly had damaging economic and social consequences for sustainable development within many countries where tourism is an important element in the economy. In some European countries, governments have put measures in place in an attempt to prevent permanent redundancies and avoid job losses but many tourism businesses, and companies which service tourism businesses, are run by independent self-employed workers and their families and are often not eligible for government support packages. More widely, outside of Europe and more specifically in many small less developed countries, such as the Maldives, the Seychelles, Grenada and St Kitts and Nevis, for example, where tourism accounts for over $50 \%$ of the Gross Domestic Product (GDP). The magnitude of direct, and more significantly indirect, job losses, in tourism caused by the COVID-19 crisis has been much greater. In some of these countries, economic activity is much more informal and millions of people hit by the COVID-19 crisis, have no other income to support themselves and their families and they, and their families, have been thrown into the poverty abyss. Such problems have almost certainly considerably set back the course of economic and social sustainable development in many parts of the world.

\section{Corporate Sustainability Programmes}

In recent years, corporate sustainability has assumed increasing importance within the business community, and many of the leading players in the tourism industry have pursued sustainability programmes designed to incorporate environmental, social, economic and governance issues into their business strategies. (e.g., Jones et al. 2014). However, COVID-19 poses a number of challenges for such programmes. On the one hand, such challenges may involve the need to respond to both investors' demands and as well as to changes in customers' tourism behaviours. Investors' demands may include promoting long term reductions in tourism companies' carbon emissions and pollution levels, greater employment of renewable energy resources, a clearer commitment to 
waste recycling and the development of circular economy principles. At the same time public health concerns, and continuing government restrictions on international travel, may be reflected in changing tourism behaviour with people choosing to take holidays within their own countries rather than to travel abroad. All of these changes may, in turn, effectively force changes in the conventional business models of many of companies in the tourism industry.

On the other hand, the COVID-19 crisis will surely reduce the availability of, and access to, capital and this may, in turn, see available financial resources being targeted on essential core business activities. At the corporate level, extensive, high profile and costly marketing campaigns designed, for example, to promote tour packages and ocean and river cruises, and to re-engage with previous customers, and investment to try to ensure that returning customers are provided with high quality experiences, may well take precedence over environmental and social agendas within corporate sustainability programmes. At the operational level, the COVID-19 crisis has highlighted the importance of greater attention being given, to basic hygiene and cleaning operations, to routine health care screening for travellers and patrons and to a greater focus on the provenance of food sourcing throughout the supply chain. At the same time, employees should be able to access regular health checks, and businesses within the tourism industry may be advised to maintain a wider welfare brief on their employees. Such measures come at a cost but they may prove important in helping to maintain a healthy workforce and regain consumer confidence and in offering a source of competitive advantage in what is likely to be an increasingly challenging marketplace.

Following the launch of the Sustainable Development Goals (SDGs) in 2016, some of the leading companies within the tourism industry have responded positively to the United Nations call for businesses to rise to the challenges and opportunities they presented. While a number of trade organisations within the tourism industry argued that tourism companies can play a major role in contributing to the SDGs, Jones and Comfort's (2019) exploratory review of the world's leading hotel groups revealed varying levels of enthusiasm for these ambitious targets. More generally in discussing the role of the private sector in contributing to the SDGs, Scheyvens et al. (2016) claimed "there is a clash between the dominant business model, which is based upon short term planning with a narrow focus on finances, and a longer term sustainable development agenda" and specifically within the tourism industry they suggested that this "is not good for sustainable, responsible destination planning, and rather it can actively undermine the wellbeing and sustainable development of destination communities."

Given such existing concerns, it remains to be seen how the COVID-19 crisis will impact upon the tourism industry's commitments to the SDG's and the situation is, at best, uncertain. On the one hand, companies may well argue that it is only by re-opening their businesses and returning to something approaching business as normal, will they have the strength and resources and be in a position to continue to contribute to the achievement of the SDGs during the next decade. In the medium term, this may encourage large companies to push back their 
existing commitments to the SDGs. On the other hand, in those areas of the less developed world where the need for many of the SDG's, focused for example, on the eradication of poverty and hunger, on the widespread availability of clean water and sanitation, and on the promotion of gender equality, are greatest, many of the limited gains made since 2015 may well have been lost in the wake of the COVID-19 crisis. Such concerns are surely heightened at a time when the Sustainable Development Solutions Network/Institute for European Environmental Policy (2019) reported that none of the countries within the European Union, let alone the less developed world, were on track to meet their SDG targets.

\section{Contradictions and Complexities}

More generally, the COVID-19 crisis has served to highlight some of the contradictions and complexities of sustainable development. On the one hand, there are inherent tensions within the concept as illustrated by the contrasts between the environmental benefits and the wide ranging economic and social costs of the COVID-19 crisis. On the other hand, there are tensions between economic forces and both environmental and social goals illustrated by some of the leading tourist companies' commitments to sustainable development. In concluding their review of the sustainability programmes being pursued by the world's leading hotel groups, Jones et. al 2014, for example, argued that "the global hotel industry's commitments to sustainability have been developed within existing capitalist business models which are focused on continuing economic growth." Here, Liverman's (2018) concerns that "growth goals cannot be met without sacrificing many environmental ones or that sustainability cannot be achieved under the current economic model of capitalism" might be seen to resonate.

At the same time, Kumar (2020) Chief Environmental Economist, United Nations Environment Programme, was reported as arguing "the emergence of COVID-19 has underscored the mutually-affective relationship between people and nature," that "we must try to understand and appreciate the limits to which humans can push nature, before the impact is negative," and that "those limits must be embraced by our consumption and production aspiration." In many ways sustainable consumption is elusive, it has no generally agreed definition, and in many ways, it is also a contradiction in terms. Indeed, sustainable consumption has been described as "the most obdurate challenge for the sustainable development agenda" (Cohen 2005), while the European Environment Agency (2020) described "unsustainable consumption" as "the mother of all environmental issues." More specifically, the United Nations World Tourism Organisation and the United Nations Environment Programme (2020) suggested that "unsustainable consumption and production practices represent one of the major barriers to sustainable development" but suggested that "the concept of sustainable consumption ana production is not commonly used by tourism policy makers." 
Increased affluence is generally seen to be one of the drivers of the growth of tourism, which people can enjoy, and arguably more importantly can afford, when they have access to the financial resources to enable them to meet what might be seen as the basic human needs of food, clothing and shelter. As tourism has become more accessible to seemingly ever larger numbers of people, this, in turn, has led to increasing demands on the earth's natural resources. In many ways, the concept of sustainable development provides a testing paradox within the tourism industry. On the one hand, the tourism industry increasingly looks to celebrate its commitment to sustainable development. Royal Caribbean Cruises (2019) for example, reported "oceans are $71 \%$ of the planet and $100 \%$ critical to our business. Conserving their health is paramount. Our 2020 environmental goals set ambitious and measurable sustainability targets to reduce our environmental footprint and raise awareness about ocean conservation."

On the other hand, the headline accent is often on conspicuous consumption, which, in many ways, is the antithesis of sustainability. Such a focus on conspicuous consumption within the tourism industry is perhaps most clearly epitomised in ocean cruising. Royal Caribbean Cruises (2016) one of the two market leaders described its ship "Freedom of the Seas," as "the ultimate in luxury." The vessel, which can accommodate 4,375 passengers, offered a main dining room with full waitress service as well as "Chops Grille," described "as a high-end grill where you'll find the likes of filet mignon and mesquite-grilled salmon on a menu that changes daily" (Royal Caribbean Cruises 2016). Carnival Corporation, the other market leader, claimed to be able to "provide our guests with virtually endless holiday choices" (Carnival Corporation 2016). Williams and Ponsford (2009) captured the paradox in drawing attention to what they described as "tourism's environmental paradox" in that tourism simultaneously seeks often fragile and sensitive environmental resources as "core ingredients and compelling backdrops for the production and consumption of tourist experiences" and "it also requires the protection of the ecological integrity and abundance of these resources for sustained competitiveness."

However, the COVID-19 crisis has opened a window on what some advocates see as a more sustainable world. In acknowledging "we are now struggling to anticipate the impacts of COVID-19" as "major financial markets are gyrating and international supply chains are in turmoil," Cohen (2020), for example, pointed out that "while the present situation is being treated as an emergent economic crisis, it merits acknowledging that sustainability scientists and policy makers have implicitly been seeking to achieve over the past decade broadly similar objectives in the form of a sustainable consumption transition." Further, Cohen (2020) argued "while it may seem fanciful and insolent, COVID-19 is an opportunity to reduce over the longer term the prevalence of lifestyle premised on large volumes of energy and material throughput" and concludes "policy makers should work to ensure that the coronavirus outbreak contributes to a sustainable consumption transition." Such a transition would demand major changes in the current business model of the vast majority of large companies in the tourism industry. At the present time, neither the majority of companies in the 
tourist industry, nor their customers, seem likely to take such an opportunity, or to have much enthusiasm for policy makers who advocate such a future.

\section{Conclusion}

This paper aimed to explore some of the realtionships between tourism and sustainable development through the lens of the COVID-19 crisis. The COVID-19 crisis has not only posed a range of complex challenges for tourist businesses but it has also exposed some new perspectives in the relationships between tourism and sustainable development. Looking forwards, it remains to be seen what the future holds, and how these relationships will be played out. On the one hand, the hope is for a return to some sort of normality, though, at the time of writing, the time scale and the extent, of such a return remains very uncertain. However, within such a scenario, many businesses within the tourism industry, and their customers, may effectively look to pick up where they left off, as part of a much wider post COVID-19 crisis recovery. Here government and corporate sustainability programmes may effectively be put on hold as capital resources are focused on economic recovery. On the other hand, the COVID-19 crisis has opened a window on some of the relationships between tourism and sustainable development, it has signalled some environmental changes that may be central to a transition to a more sustainable future, it has highlighted some of the inherent contradictions and complexities within the concept of sustainable development and it has offered some radical solutions to the challenges of sustainability. Whether tourism businesses, large and small, or the vast majority of their customers, will want to recognise the significance of such signals and have any genuine enthusiasm for such solutions remains very much to be seen.

The authors recognise that the paper has its limitations, not least that it draws exclusively on secondary sources drawn from the Internet. This reflects the reality that both the authors were in lockdown, and that for a number of reasons, traditional avenues of empirical research were not open to them. Nevertheless, the authors believe that the paper offers an important snap shot in time of the impact of COVID-19 on the relationship between tourism and sustainable development and provides a valuable platform for future research. Looking to the future, a number of conceptual and research issues merit the attention of tourism scholars. In addressing the continuing importance of developing and refining conceptual frameworks connecting nature and society, two sets of issues merit attention.

In addressing the continuing importance of developing and refining conceptual frameworks connecting nature and society, two sets of issues merit attention. Firstly, for those scholars who have drawn on stakeholder theory to conceptualise sustainability, the COVID-19 crisis certainly emphasises the need to integrate the interests of a wider range of stakeholders including, all employees, customers and society at large to provide a more comprehensive theoretical approach to sustainable development. Secondly, some the relationships between the tourism industry and sustainable development exposed by the COVID-19 crisis, seem valuable in informing to a more critical theory of sustainability, which 
seeks to locate sustainable development within wider economic, social and political structures. While stakeholder theory has been widely employed to explore sustainable development within the tourism industry, very limited attention has been given to more critical conceptual approaches. This is perhaps not altogether surprising given the, often close, working and professional relationships between many tourism scholars and an industry which is committed to growth, and where radical ideas have a limited constituency. Nevertheless, this is certainly a lacuna which merits future research.

At the empirical level, there are a wide range of research opportunities across a range of sub disciplines but three simple examples serve to illustrate the potential scope for work on the impact of the COVID-19 crisis on sustainable development within the tourism industry. In marketing, for example, market research designed to explore consumers' attitudes to a range of tourism activities and destinations at both a local and an international level, will shed light on if, and how, such customers are changing their behaviours in the light of the COVID-19 crisis. Research might also focus on the impact of the COVID-19 crisis on the management of supply chains within the tourism industry and perhaps more specifically on the issue of provenance within the food supply chain. Research into how information and communication technologies are being employed to help to address continuing customer safety concerns would also seem to offer fertile ground for future research.

\section{References}

Carnival Corporation (2016) Corporate information. Retrieved from: https://bit.ly/ 3bO6WsN. [Accessed 17 March 2016].

Cohen MJ (2005) Sustainable consumption in national context; an introduction to the symposium. Sustainability: Science, Practice, \& Policy 1(1): 22-28.

Cohen MJ (2020) Does the COVID-19 outbreak mark the onset of a sustainable consumption transition? Sustainability: Science, Practice, \& Policy 16(1): 1-3.

de Sausmarez N (2007) Crisis management, tourism and sustainability: the role of indicators. Journal of Sustainable Tourism 15(6): 701-714.

Di Marco M, Baker L, Daszak P, De Barro P, Eskew EA, Godde CM et al. (2020) Opinion: sustainable development must account for pandemic risk. Proceedings of the National Academy of Sciences of the United States of America 117(8): 38883892.

European Environment Agency (2020) Unsustainable consumption - the mother of all environmental issues? Retrieved from: https://bit.ly/3fYQ1Y9. [Accessed 27 April 2020]

Hall CM, Gossling S, Scott D (2015) Tourism and sustainability: an introduction. In CM Hall, S Gossling, D Scott (Eds), 1-12. The Routledge Handbook of Sustainable Tourism. London: Routledge.

Jones P, Hillier D, Comfort D (2014) Sustainability in the global hotel industry. International Journal of Contemporary Hospitality Management 26(1): 5-17.

Jones P, Comfort D (2019) Sustainable development goals and the world's leading hotel groups. Athens Journal of Tourism 6(1): 1-14. 
Kumar P (2020) COVID-19 and the nature trade off paradigm. UN Environment Programme. Retrieved from https://bit.ly/3bNOm4a. [Accessed 17 April 2020].

Liverman D (2018) Geographical perspectives on development goals: constructive engagement and critical perspectives on the MDs ad the SDGs. Dialogue in Human Geography 8(2): 168-185.

Neisdadt M (2020) COVID-19 and the tourism sector. European Parliamentary Research Service. Retrieved from: https:// https://bit.ly/3g1cJPh. [Accessed 3 May 2020].

Organisation for Economic Cooperation and Development - OECD (2020) Tackling coronavirus (COVID-19), contributing to a global effort: tourism responses. Retrieved from https://bit.ly/2zOH8Qg. [Accessed 3 May 2020].

Royal Caribbean Cruises (2016) Freedom of the seas. Retrieved from: https://bit.ly/ 2Xo8FAf. [Accessed 21 March 2016].

Royal Caribbean Cruises (2019) Sustainability 2018. Retrieved from: https://bit.ly/ 2X5PzP0. [Accessed 5 May 2020].

Scheyvens R, Banks G, Hughes E (2016) The private sector and the SDGS: the need to move beyond business as usual. Sustainable Development 24(6): 371-382.

Segal S (2020) The global impacts of COVID-19. Retrieved from: https://www. csis.org/analysis/global-economic-impacts-covid-19. [Accessed 17 April 2020].

Statista (2020) Number of jobs at risk in the tourism sector in European countries due to coronavirus (COVID-19) pandemic. Retrieved from: https://bit.ly/2zRMH02. [Accessed 3 May 2020].

Sustainable Development Solutions Network/Institute for European Environmental Policy (2019) European sustainable development report: towards a strategy for achieving the sustainable development goals in the European Union. 2019. Retrieved from: https://bit.ly/2WHbvAU. [Accessed 11 March 2020].

United Nations Department of Economic and Social Affairs (2020) World economic situation and prospects: April 2020 briefing, No. 136. Retrieved from: https:// www.un.org/development/desa/dpad/publication/world-economic-situation-andprospects-april-2020-briefing-no-136/. [Accessed 19 April 2020].

United Nations World Tourism Organization (2020) Impact assessment of the COVID19 outbreak on international tourism. Retrieved from: https://bit.ly/36 gm4hM. [Accessed 3 May 2020].

United Nations World Tourism Organization and the United Nations Environment Programme (2020) Baseline report on the integration of sustainable consumption and production pattens into tourism policies. Retrieved from: https://bit.ly/2Zg ZB2v. [Accessed 4 May 2020].

Ural M (2015) Risk management and sustainable tourism. European Journal of Tourism, Hospitality and Recreation 7(1): 63-71.

Williams PW, Ponsford IF (2009) Confronting tourism's environmental paradox: transitioning for sustainable tourism. Futures 41(6): 396-404.

World Commission on Environment and Development (1987) Our common future. Retrieved from: https://bit.ly/2ZjgOsi. [Accessed 17 April 2020].

World Economic Forum (2020) COVID-19: What you need to know about the coronavirus pandemic on 4 April. Retrieved from: https://bit.ly/3bLx1sL. [Accessed 6 April 2020]. 



\title{
The Impact of the Covid-19 Pandemic on Greek Tourism
}

\author{
By Gregory T. Papanikos*
}

\begin{abstract}
This paper examines the economic impact of the 2020 pandemic on international Greek tourism receipts. The uncertainty and risk surrounding the epidemiological conditions make any reliable prognosis of the 2020 and beyond almost impossible. This study relies on information regarding the international pre-bookings of European destinations. According the to the European Union's Travel and Tourism Industry, pre-booking have fallen by 60 to 90 percent. Using these two extreme values and the average of the two, this study develops three scenarios to examine the impact of the pandemic on Greek tourism. In the best of the three scenarios, the contribution of Greek tourism to GDP will drop from 16\% in 2019 to $6.6 \%$ in 2020. The output loss amounts to $€ 16.8$ billion.
\end{abstract}

Keywords: Pandemic, Covid-19, crisis, tourism, Greece, economic impact

\section{Introduction}

In 2019, 34 million tourists arrived in Greece from different countries generating $€ 18.2$ billion of international tourist receipts. These were historical record numbers for the Greek tourism industry. In addition, 2020 looked even brighter till the pandemic outbreak mid-March in Greece. The lethal infectious disease (Covid-19) hit the Asian countries first and then spread out to Europe and eventually to the rest of the world. Almost all countries banned international travel. The Greek tourism market collapsed as did all the tourism markets in the world and especially in Europe.

Greece belongs to the European Union and is a member of the Eurozone since its inception in 2002. Regrettably for all those who believe in the so-called European Project, the European Union's reaction to the current pandemic has been far-fetched. There was a complete lack of co-ordination and each member state has been applying its own policies violating the principle of the freedom of movement of goods and people.

The recent (13 May 2020) ${ }^{1}$ releases of a series of documents adopted by the European Commission demonstrate the weakness of the most important European Institution to take a strong position on the issue and most importantly coordinate their actions. By a strong position, I mean evidence-based criteria to be applied by the countries concerned. For example, if the daily number of people infected is below 10 for 14 days (the minimum time required to recuperate from the disease), then this country can be declared pandemic free. Travel between such countries should be allowed. The European Commission made a number of proposals which do not address the problem in practical business-like terms. They wish that

${ }^{*}$ President, Athens Institute for Education and Research (ATINER), Greece.

${ }^{1}$ See European Commission (2020a, 2020b, 2020c, 2020d). 
international travel is permitted if the epidemiological situation improves. But how does one define improvement? And under what conditions such travels will be permitted? In this paper, I do provide some evidence what it could be meant by improvement.

Pandemics in economics are analysed as external shocks similar to other events such as earthquakes, floods, droughts, wars, terrorist attacks etc. A recent short overview is given by Rasul (2020). Theoretical and empirical studies of pandemics have shown mixed results even though most of them point towards an overall negative effect; in the short, medium and long run. Some of these studies are briefly reviewed in the next section of the paper. The most important constraint of economic impact analyses of previous pandemics is the availability of data. This explains why most economic impact studies use the 1918 epidemic and other smaller outbreaks of the $20^{\text {th }}$ and $21^{\text {st }}$ century as their natural experiments to examine economic impacts. On the other hand, the social and political impacts are easier to assess because there are references made to them. The first well known epidemic of 430 BCE narrated by Thucydides in his work of the Peloponnesian War (Papanikos 2020) has a detailed exposition of the social, political and anthropological effects of the plague. Unlike Pericles, Thucydides himself was infected and survived.

The current Covid-19 pandemic has a particularity when is compared with the 1918 epidemic; never before people travelled so much for business, education and recreational (pleasure) purposes. The travel industry in 2020 cannot compare to what this was in 1918; almost non-existent. The pandemic hit badly damaged the tourism industry by completely shutting down the supply and the demand of tourism services. It can be thought of as a market failure to satisfy a potential demand. But there is more than that. It is not economics that determine the outcome of the tourism market but epidemiology. It is not the invisible hand of the market but the invisible virus of the coronavirus. This explains the difficulty in providing forecasts of the economic impact of the pandemic on the tourism market even if one asks the Oracle of Delphi (i.e., applying the Delphi Method); economics play little or no role at all. The existence or not of the market is determined by the harshness of the pandemic which create enormous uncertainty and uncalculated risks.

Despite all these deficiencies, this paper attempts to estimate the impact of the current pandemic on the international Greek tourism market. The literature review looks to shed some light on the possible effects on the aggregate economy and the tourism market in particular. An eclectic review of this literature is given in the next section of the paper. Some leading indicators of the pre-booking cancellation are used to develop three possible scenarios. These are examined in the third section of the paper. The most important determinant of the tourism impact is the lift of the lockdown -conditionally or unconditionally. The fourth section look at this issue using data of the number of people infected in 19 countries which constitute the most important earning source (two-thirds) of total international Greek tourism receipts. The last section of the paper concludes. 


\section{The Impact of Pandemics in an Historical Context}

Lack of data restricts economic impact analyses of pandemics. Papanikos (2020) examined the famous ancient plague narrated by Thucydides and made a comparison with the synchronous pandemic of 2020. The comparison was made in terms of individual, social and political effects. Data are not available to make an economic impact analysis. In addition, the co-existence of a war and a plague makes the impact evaluation of the ancient Athenian plague very difficult indeed. This might also be the case of the 1918 epidemic because occurred immediately after the First World War if not during the war.

A number of studies had been published before the outbreak of the synchronous pandemic which attempted to assess the economic impact of a pandemic. All of these studies suffer from methodological problems which are mainly the result of lack of data and have been recognized by authors themselves. These studies use a rule of thumb methodology, back of the envelope calculations and anecdotal evidence to measure the economic impact. Despite all these problems their estimates seem to be comparable with what current research has provided for the synchronous pandemic. Studies have measured the overall economic impact of more recent pandemics. Eichenbaum et al. (2020) developed a theoretical epidemiology model to study the impact of the synchronous pandemic. The best policy is containment which increases the severity of the recession but according to their benchmark estimates 500 thousand lives would be saved in the USA. However, this study does not measure the lives lost if the reduction in economic growth has a negative impact in infant mortality.

Meltzer et al. (1999) estimated the possible effects of a hypothetical influenza pandemic in the United States. They used death rates, hospitalization data, and outpatient visits. They reported estimations of 89,000 to 207,000 deaths; 314,000 to 734,000 hospitalizations; 18 to 42 million outpatient visits; and 20 to 47 million additional illnesses. Their estimated economic impact was between 0.7 and 1.7 percent of GDP. Jordà et al. (2020) studied 15 major pandemics going back to $14^{\text {th }}$ century by looking at the rates of return on assets. They found persistent negative after-effects that lasted for about 40 years. Interestingly, they found a positive effect of wars. Ma et al. (2020) used panel data of 210 countries for the 1960-2018 period. They observed a 2.57 percent negative impact on real GDP. Policy interventions early on had a mitigated effect on the reduction of economic growth. Most studies take advantage of data availability of the 1918-1920 epidemic (so called the Spanish Flu). Barro et al. (2020) looked at this epidemic using data from 43 countries. For an average country, they found an economic contraction of 6 to 8 percent. Garrett (2007) also examined the 1918-1920 epidemic. Recognizing the lack of economic data, the study relied on anecdotal evidence and print media to assess the economic impact of the epidemic. The author, in his opening paragraph, stated that 'The possibility of a worldwide influenza pandemic (e.g., the avian flu) in the near future is of growing concern for many countries around the globe.'

The author used influenza mortalities in the Cities in the Eighth District States of the USA. The economic impact is based on anecdotical evidence of print media. They do, however, provide useful information. Here is a compilation. 'Merchants 
in Little Rock say their business has declined 40 percent. Others estimate the decrease at 70 percent.' 'The retail grocery business has been reduced by onethird.' 'One department store, which has a business of \$15,000 daily $\$ 200,265$ in 2006 dollars), is not doing more than half that.' 'The only business in Little Rock in which there has been an increase in activity is the drug store. Fifty percent decrease in production reported by coal mine operators.' These numbers look similar to the effects of the current pandemic reports. For example, these are about the same estimates of OECD (2020) for the current pandemic impact on tourism.

Garrett (2007) observed that cities and states having greater influenza mortalities experienced a greater increase in manufacturing wage growth over the period 1914 to 1919. This is because the capital-labor ratio increased due to the higher mortality rate. The author concluded that 'Society as a whole recovered from the 1918 influenza quickly, but individuals who were affected by the influenza had their lives changed forever. Given our highly mobile and connected society, any future influenza pandemic is likely to be more severe in its reach, and perhaps in its virulence, than the 1918 influenza despite improvements in health care over the past 90 years. Perhaps lessons learned from the past can help mitigate the severity of any future pandemic.'

Many other studies have studied the economic impact of the 1918 epidemic with mixed results. Studies found positive long-term impacts. Brainerd and Siegler (2003) model the 1918 epidemic as an exogenous shock to the USA economy. They used data from 1919 to 1930 . They controlled for a number of factors such as initial income, density, urbanization, human capital, climate, the sectoral composition of output, geography, and the legacy of slavery. They found a robust positive effect of the 1918 epidemic on per capita income across states during the period under investigation. Almond (2006) used the 1918 epidemic as a data generation process of a natural experiment to test the fetal origins hypothesis. $\mathrm{He}$ found that fetal health affected almost all socioeconomic groups recorded in the 1960, 1970, and 1980 Censuses. Those who were in utero during the epidemic of 1918 and their mothers were infected; they had a 15 percent lower probability to finish high school. Also, men's wages were 5 to 9 percent lower. Correia et al. (2020) used geographic variations in mortality rates of the 1918 epidemic in the USA. They found that manufacturing output decreased by 18 percent which was the result of the co-movements of both the supply and demand. They also looked at government intervention initiatives at the city level. Cities which intervene earlier and more aggressively had better economic performance and they grew faster after the epidemic was over.

World Bank (2017) published a report with estimates of GDP loss during a pandemic. They used a methodology based on the study of Fan et al. (2015). As far as Greece is concerned, the World Bank estimated that the loss would amount to 0.44 percent of its GDP. The Global effect was estimated to be 0.7 percent of GDP.

It remains to be seen what the final impact of from the Covid-19 2020 pandemic will be and previous studied may not necessarily be the best guide. In a case study of Sierra Leone of the 2014-16 Ebola outbreak, Bandiera et al. (2018) found a decrease in income of 10.9 percent. The government actions were 
identical to the measures taken by many governments to cope with the 2020 pandemic: (a) lockdowns and travel bans, (b) all schools were closed and (c) there was a mobilization to record cases and track contagion. These have had dire effects on economic activity; especially the travel bans and the lockdown of shops had devastated effect on tourism. This has been the Greek case which is examined next.

\section{The Greek Tourism Market under the Pandemic}

The literature on pandemics suggests that the short-run impacts are considerable but the long term ones are more positive. The economic textbook circular flow assumes that suppliers (businesses) and households freely interact in the factor and product market incurring the relevant costs and generating revenues. Any intervention by an external agency (e.g., government, trade union, employees' associations) or contingency (e.g., a war, a terrorist attack, an earthquake) have an impact on the demand and supply of the final product (e.g., recreational tourism services) and all the intermediate products and factors of production required to produce the final product. Applying this to tourism, economists using their analytical tools can estimate the effect of any intervention on the demand and supply side of tourism services.

However, the current situation of the pandemic's impact on the supply and demand of tourism services cannot be analysed using the traditional tools of economic analysis. The impact of the pandemic cannot be analysed as an external shock. This is normally done when a negative external shock impinges on the supply and demand of a product (e.g., hotel services), or the demand and supply of an entire economic sector (e.g., tourism industry) or on the aggregate economy.

The 2020 pandemic impact is different. Its effect cannot be measured as a shift of the demand and/or supply curves because simply these curves do not exist. For example, due to the coronavirus, there is neither supply nor demand for tourism services. When the coronavirus closes a hotel, the service of this hotel does not exist anymore. When a country forbids its citizens to travel abroad, this is not a shock on the demand curve (the demand curve does not shift to the left) but the demand collapses, i.e., it does not exist anymore. There is a potential demand but this cannot be realized under a situation of uncertainty and risk that a pandemic creates. Thus, there is no economic policy that can solve this problem when for medical and institutional reasons the market is forced to shut down its operation on both the supply and the demand side. That is an economic policy which can open up the market by removing the barriers to trade.

It is not an economic problem; it is a medical (epidemiological) problem which has serious economic and social repercussions including the entire process of sustainable development and tourism ${ }^{2}$. It is the subject matter of infectiology.

\footnotetext{
${ }^{2}$ The effect of the Covid-19 crisis on tourism and sustainable development is examined in Jones and Comfort (2020). The authors offer an excellent recent overview of the relationship between tourism and sustainable development and conclude with some policy and research suggestions at the level of government and business. Prudently so they emphasize that their paper is not an empirical one
} 
Economists cannot forecast the impact till the infectiology will determine when the circular flow of the tourism market can be set in operation again. Until the Covid-19 pandemic runs its course-and the conditional or unconditional opening of the market begins to take place, economic analyses may have limited value. Conditional means that the terms of trade will change which will result in an increase in costs. Then economists can be useful; at the extreme what is epidemiologically or politically feasible may not be economically operational and there will be a market failure because of the constraints imposed on it.

What is optimal from a medical point of view in air travel (e.g., 40 percent capacity) may be prohibited from an economic point of view because such capacity rates do not cover the fixed cost of operation. And the economic textbook has a dismal prognosis of what happens to the business in such situations. In the Greek context of so many small islands and small hotels ${ }^{3}$, strict recommendations as the ones proposed by the European Commission in its recent documents exclude many small Greek destinations. For example, they recommend full-fledge hospital and medical facilities. The numerous small touristic islands have serious problems of providing basic health services in normal (non-epidemic) situations. If such restrictions are imposed, the small islands tourism markets will collapse. Their hotels can open to satisfy any demand.

The economic impact of a closed market is very simple to estimate. The impact on the Greek tourism of a closed market in 2020 is equal to the tourism multiplier (e.g., 1.6) multiplied by tourism receipts ${ }^{4}$. If we assume that the international tourism receipts would have remained the same as in 2019 without the pandemic, then in the second quarter of the 2020, Greece will forego international tourism receipts of 5 billion euro ${ }^{5}$. If they stay closed for the rest of 2020 , then the foregone international tourism income would be 17.4 billion euro. Thus, the direct effect will be 17.4 billion euro and the total effect $17.4 \times 1.6=27.9$ billion euro or 15 percent of the Gross Domestic Product (GDP). And this does not take into consideration the domestic tourism which is not small either.

According to estimates reported by the European Commission (2020a, p. 9) '...revenue losses at European level have reached $50 \%$ for hotels and restaurants, $85 \%$ for tour operators and travel agencies, $85 \%$ for long-distance rail and $90 \%$ for cruises and airlines. EU travel and tourism industry reports a reduction of bookings in the range of $60 \%$ to $90 \%$, compared to the corresponding periods in previous years. The crisis has hit SMEs the hardest: lacking liquidity and facing uncertainty, they struggle to stay afloat, access funding and maintain their employees and talent.'

Households face uncertainty and risk as well. Even if the lockdown is lifted tomorrow, the uncertainty and the risk will remain and this will affect the demand

because of the uncertainty involved. The key issue is when the pandemic will be terminated and so far, this does not look very promising.

${ }^{3}$ I have examined elsewhere in detail the economics and the employment of Greek Hotel Enterprises at the aggregate and regional level; see Papanikos (2000, 2001, 2002).

${ }^{4}$ See European Commission (2020a, pp. 7-8). They give an average tourism multiplier of 1.56 for all the European Union. For Greece, is a little bit higher.

${ }^{5}$ Tourism data is retrieved from The Border Survey conducted and reported by Bank of Greece (https://www.bankofgreece.gr/en/statistics/external-sector/balance-of-payments/travel-services). 
for tourism and especially international tourism. To be fair, the European Commission has recognized this important aspect of the tourism market and has outlined measures and guidelines which can reduce the uncertainty and risk by disseminating in real time all available information using the modern information technology and communications. But this may have the opposite effect. When the consumer is informed (he will receive a message in real time) that where he plans to travel (a small Greek island) there is a case of someone being infected, then he would think twice before taking the trip. Once on the island, if he receives such a message, all tourists would want to get out as soon as possible. Under such circumstances, Greek tourism will suffer not this year only. And this will interrupt an unprecedented tourism growth in the last two decades. Table 1 shows the recent history of international Greek tourism in terms of receipts and arrivals ${ }^{6}$. As a percentage of GDP, international tourism receipts increased their GDP share from 5 percent in 2005 to almost 10 percent in 2019. Both GDP and tourism receipts are expressed in nominal terms. Thus, comparisons overtime can be made only using the percentage of tourism receipts to GDP.

Table 1. International Tourism Arrivals and Receipts, 2005-2019

\begin{tabular}{|c|c|c|c|c|c|}
\hline Year & $\begin{array}{c}\text { Int'l } \\
\text { Tourism } \\
\text { Receipts } \\
\text { Billion } €\end{array}$ & $\begin{array}{c}\text { Int'l Tourism } \\
\text { Arrivals } \\
\text { Millions of } \\
\text { Tourists }\end{array}$ & $\begin{array}{c}\text { Spending per } \\
\text { Tourist } \\
\text { Arrival } \\
€\end{array}$ & $\begin{array}{c}\text { GDP } \\
\text { Billion } \\
€\end{array}$ & $\begin{array}{c}\text { Tourism } \\
\text { Receipt } \\
\text { as a \% of } \\
\text { GDP }\end{array}$ \\
\hline 2005 & 10.73 & 14.39 & 746 & 199.2 & $5.39 \%$ \\
\hline 2006 & 11.36 & 15.23 & 746 & 217.9 & $5.21 \%$ \\
\hline 2007 & 11.32 & 16.17 & 700 & 232.7 & $4.86 \%$ \\
\hline 2008 & 11.64 & 15.94 & 730 & 242.0 & $4.81 \%$ \\
\hline 2009 & 10.40 & 14.91 & 697 & 237.5 & $4.38 \%$ \\
\hline 2010 & 9.61 & 15.01 & 640 & 226.0 & $4.25 \%$ \\
\hline 2011 & 10.50 & 16.43 & 639 & 207.0 & $5.07 \%$ \\
\hline 2012 & 10.44 & 16.95 & 616 & 191.2 & $5.46 \%$ \\
\hline 2013 & 12.15 & 20.11 & 604 & 180.7 & $6.73 \%$ \\
\hline 2014 & 13.39 & 24.27 & 552 & 178.7 & $7.50 \%$ \\
\hline 2015 & 14.13 & 26.11 & 541 & 177.3 & $7.97 \%$ \\
\hline 2016 & 13.21 & 28.07 & 470 & 176.5 & $7.48 \%$ \\
\hline 2017 & 14.63 & 30.16 & 485 & 180.2 & $8.12 \%$ \\
\hline 2018 & 16.09 & 33.07 & 486 & 184.7 & $8.71 \%$ \\
\hline 2019 & 18.18 & 34.00 & 535 & 187.5 & $9.70 \%$ \\
\hline
\end{tabular}

Data Source: GDP (AMECO). International Tourism Receipts (Bank of Greece).

This past positive history of international tourism receipts will surely come to an end in 2020. Unfortunately, it is very difficult to foresee the economic impact of a pandemic in general and on tourism in particular. Everything depends on the epidemiological variables. The key question is the termination of the pandemic. Once this is determined, then a process of recuperating starts which results to an

${ }^{6}$ I have examined these in detail in by book on Greek tourism receipts; see Papanikos (2005). 
increasing rate of economic growth. The empirical evidence is mixed on this issue and there seems to be both transitory and permanent effects. In some cases, the effect might be a strong positive one if the economy does not suffer losses of its productive human capital. But even if it suffers such a loss, the negative effect is mitigated by an increase in the capital-labour ratio.

In this study, I use the leading indicators provided by the early bookings for tourism destinations. According to the European Commission report (cited previously), the European Union's travel and tourism industry has experienced a reduction in tourism bookings in the range of 60 percent to 90 percent. These reductions include cancellation of many events such as conferences, festivals, cruises, etc., which have been permanently cancelled. In Greece almost all summer sports, cultural and educational events have been cancelled or postponed. These events attract hundreds of thousands of people.

I assume that the pandemic had a very small (5 percent) impact in the first quarter of 2020. I then make three scenarios of an overall reduction of 90 percent, 75 percent and 60 percent. The estimates are shown in Table 2. Three scenarios are reported assuming (a) a reduction of 90 percent which implies that only 10 percent of tourism receipts will be made relative to 2019; (b) a reduction of 75 percent and (c) a reduction of 60 percent. The latter is the best-case scenario. Alternatively, one could envisage scenarios that the reduction rate of 90 percent is reduced throughout the rest of the 2020 but the critical issue is when the lockdown will end. This is a situation of uncertainty and not one of risk.

Table 2. The Pandemic Impact on Greek Tourism: A Scenario Analysis

\begin{tabular}{|c|c|c|c|c|c|c|c|}
\hline & $\begin{array}{c}2019 \\
\text { Actual } \\
(€ \mathrm{M})\end{array}$ & $\begin{array}{c}\text { Coef. } \\
\text { A }\end{array}$ & $\begin{array}{c}2020 \\
\text { Scenario A } \\
(\text { worst } \\
\text { case) }\end{array}$ & $\begin{array}{c}\text { Coef. } \\
\text { B }\end{array}$ & $\begin{array}{c}2020 \\
\text { Scenario } \\
\text { B } \\
\text { (average) }\end{array}$ & $\begin{array}{c}\text { Coef. } \\
\text { C }\end{array}$ & $\begin{array}{c}2020 \\
\text { Scenario C } \\
\text { (optimistic) }\end{array}$ \\
\hline Q1 & 747 & 0.95 & 709 & 0.95 & 709 & 0.95 & 709 \\
\hline Q2 & 4667 & 0.1 & 467 & 0.25 & 1167 & 0.4 & 1867 \\
\hline Q3 & 10693 & 0.1 & 1069 & 0.25 & 2673 & 0.4 & 4277 \\
\hline Q4 & 2072 & 0.1 & 207 & 0.25 & 518 & 0.4 & 829 \\
\hline $\begin{array}{c}\text { Total } \\
\text { (Year) }\end{array}$ & 18179 & & 2452 & & 5067 & & 7682 \\
\hline $\begin{array}{c}\% \text { of } \\
2019\end{array}$ & & $13.5 \%$ & & $27.9 \%$ & & $42.3 \%$ \\
\hline $\begin{array}{c}\% \\
\text { Reduction }\end{array}$ & & $86.5 \%$ & & $72.1 \%$ & & $57.7 \%$ \\
\hline $\begin{array}{c}\text { GDP } \\
\text { Impact }\end{array}$ & 29086 & & 3924 & & 8108 & & 12291 \\
\hline $\begin{array}{c}\% \text { of } \\
\text { GDP } \\
\text { Impact }\end{array}$ & $16 \%$ & & $2.1 \%$ & & $4.3 \%$ & & $6.6 \%$ \\
\hline
\end{tabular}

In 2019, international tourism receipts amounted to a total of 18.2 billion euro but more than half (59 percent) of these were realized in the third quarter of the year; 26 percent in the second quarter; and 11 percent in the last quarter. Only 4 
percent of the receipts were made in the first quarter of 2019. Assuming that these proportions will remain the same in 2020 -the seasonality of Greek Tourism is one of its permanent features-, the impact of the pandemic on the tourism receipts can be estimated using the range of the fall of pro-booking of 60 percent to 90 percent. These result to three impact coefficients of 0.1 in the worst-case scenario, 0.25 in an average scenario and 0.4 in an optimistic scenario.

In the worst-case scenario the overall decrease in tourism receipts is 86.5 percent relative to 2019 . From 18.2 billion, receipts will decrease to 2.5 billion. Assuming a multiplier effect of 1.6, then the impact on Greek GDP is a reduction of 13.9 percent relative to 2019 (16 percent-2.1 percent). In 2019 the international tourism contribution to GDP was $€ 29.1$ billion (16 percent) while it is expected to be only $€ 3.9$ billion in 2020 if the worse-case scenario is realized (2.1 percent of GDP). That said, as many studies have shown of previous pandemics, the overall GDP impact depends on how strong and how fast is the government intervention. In the case of Greece, government reacted quickly providing income to employees and liquidity to employers who were affected by the lockdown. The best-case scenario still assumes a considerable reduction in tourism receipts; from $€ 18.2$ billion in 2019 to $€ 7.7$ billion. The loss of output relative to 2029 is $€ 16.8$ billion (29.1-12.3). In this optimistic scenario the tourism contribution to Greek GDP is 6.6 percent as opposed to 16 percent in 2019.

\section{Predicting the Lockdown Lift}

When should countries lift the lockdown? This is a very difficult decision to make and the European Commission does not provide any criteria for the lifting of the lockdown on international tourism. Rather, it vaguely refers to a better epidemiological situation. How should a critical situation be defined? What is the threshold between lifting and not lifting the lockdown? But what are the cost and benefits of a lockdown? How should they be measured? Do they add up arithmetically or geometrically? Does the lockdown costs only a reduction of economic growth (loss of GDP) or it costs lives as well? How do we evaluate the loss of lives due to coronavirus against the loss of human lives due to a reduction in economic growth? The relationships between economic growth and health variables such as longevity and mortality rate (especially infant mortality) have been well documented in the theoretical and empirical economic literature; see among many others the studies by Niu and Melenberg (2014), Hanewald (2011), Swift (2011), and Kalemli-Ozcan (2002). The causality may run both ways. An initial increase in income or per capita income or its distribution may positively affect longevity and quality of health, which, in turn, through its human capital effect may increase per capita GDP. If tourism enhances human capital -this is the case when recreation and leisure activities are considered a necessity-, this results in future raises of the productivity of labour.

In conclusion of this literature, the trade-off may be evaluated in terms of human lives lost and saved. If a slowdown of economic growth due to the lockdown increases infant mortality and the coronavirus increases the mortality 
rate of elderly with underlying chronic medical problems, what is the optimal size of a lockdown in terms of its length of time and width of economic activities covered? These issues have not been addressed in the current debate of the lockdown due to Covid-19. But they are important.

If a country aims at eliminating the risk of spreading the disease, then it should lift its travel bans only when at least the 14-days moving average of the reported cases of the country of origin is zero. This does not eliminate the risk because the number of reported cases is an underestimation of the true cases; the latter include people who are infected but they show no symptoms. Another indicator would be the number of deaths but this can be an overestimation because people with underlying chronic diseases should be excluded. I give the following real example. An old woman of 93 years old with bad medical history died due to the coronavirus in Athens. Her death made headlines. The same day a young male of 30 years old without any health problem died in a traffic accident. His death hardly made it through the news. From an economic point of view, the two deaths are not two more numbers. Even from a compassionate point of view the two deaths do not carry the same weight. This appears to be the case with the synchronous pandemic. Health economists have developed their own methodology in evaluating the value of lives lost.

Table 3. Reported New Cases of Covid-19 Infections (14-Days Moving Average) and Tourism Receipts by the Most Important Countries of Origin

\begin{tabular}{|l|c|c|c|}
\hline \multicolumn{1}{|c|}{ Country } & $\begin{array}{c}\text { Receipts } \\
€ \mathrm{M}\end{array}$ & $\begin{array}{c}\% \text { of } \\
\text { Total Receipts }\end{array}$ & $\begin{array}{c}\text { As of 15 May, 2020 } \\
\text { (14-days MA) }\end{array}$ \\
\hline Germany & 2959 & $16.3 \%$ & 1002 \\
\hline United Kingdom & 2564 & $14.1 \%$ & 3978 \\
\hline USA & 1189 & $6.5 \%$ & 22517 \\
\hline France & 1090 & $6.0 \%$ & 745 \\
\hline Italy & 1009 & $5.5 \%$ & 1119 \\
\hline Netherlands & 534 & $2.9 \%$ & 264 \\
\hline Romania & 483 & $2.7 \%$ & 263 \\
\hline Cyprus & 465 & $2.6 \%$ & 4 \\
\hline Switzerland & 462 & $2.5 \%$ & 54 \\
\hline Austria & 462 & $2.5 \%$ & 39 \\
\hline Belgium & 453 & $2.5 \%$ & 375 \\
\hline Russia & 433 & $2.4 \%$ & 18 \\
\hline Australia & 371 & $2.0 \%$ & 1441 \\
\hline Canada & 343 & $1.9 \%$ & 504 \\
\hline Sweden & 258 & $1.4 \%$ & 8 \\
\hline Albania & 212 & $1.2 \%$ & 1023 \\
\hline Spain & 203 & $1.1 \%$ & 100 \\
\hline Denmark & 191 & $1.0 \%$ & 44 \\
\hline Czech Republic & 184 & $1.0 \%$ & 2285 \\
\hline Total & 13864 & $76.3 \%$ & $2 \%$ \\
\hline
\end{tabular}

Note: Data on Covid-19 infections was retrieved from the online database maintained by the John Hopkins University (https://coronavirus.jhu.edu/map.html). 
If the country accepts non-zero cases, then a threshold can be established. Table 3 reports data on Greek International Tourism receipts by top countries of origin. In total these countries made up the 76 percent of total Greek international tourism receipts. Germany is at the top with almost $€ 3$ billion in 2019 followed by U.K. and USA. Which markets opens depends on the thresholds imposed by the home and the destination country. Suppose Greece imposes a restriction that no tourists can visit Greece coming from countries that in the last 14-days had a nonzero average of new cases. This is met only if in the last 14 days, the country did not report a single case. It is obvious from Table 3 that no country meets this criterion as of 15 May 2020 and it is not going to satisfy this criterion by the end of May as well.

If Greece imposes a 14-days moving average of less than one thousand, then many countries will be excluded such as Germany, USA, UK, Italy and Spain. Of course, this criterion must be combined with the rate of increase. It must be negative otherwise there is always the risk of a second wave (spike) which many epidemiologists expect to happen by the end of the summer. In this case the criterion is enhanced to include the rate of decrease of the spread of the disease. Thus, Greek tourist authorities must take some difficult decisions, especially when deciding to open up the island tourism market which so far have had zero cases of infected people. Some islands such as Crete, Rhodes and Corfu have a welldeveloped hospital sector and they can deal with an emergency situation but the other islands do not have such facilities. However, the risks may be-even higher if the epidemiological protocols are followed. Assume that in a small island of Greece a tourist tests positive to Covid-19. As normal tourists do, he visited all the places of the small islands (e.g., museums, beaches, bars, restaurants etc.) and got in conduct with many tourists and locals. The entire island must be put on quarantine for at least 14 days. Very few will risk such a vacation experience.

Unless the pandemic is over, such risks impose nonzero economic and social costs. And as such they will considerably reduce the international and national demand for tourism. The tourism market will start returning to its pre-pandemic years only if the 14-days moving average is reduced to zero. And even then, some months or even years may be required before the uncertainty and the risks are eliminated. Tourism for recreational purposes cannot co-exist with the fear of an infectious disease. Actually, it cannot exist with any fear such as wars, earthquakes, political unrest, climate changes etc.

\section{Conclusion}

The economic impact of any pandemic is very difficult to measure including the number of people contracting the virus and dying. The review of the literature shows that the effects (positive and negative) can be immediate due to lockdown, medium due to time required to adjust to a pre-pandemic state and long-run through its effect on human capital which might last more than one generation as this has been demonstrated by the empirical verification of the fetal origins hypothesis. Based on the leading indicators of pre-bookings this study has found 
that the impact of the 2020 pandemic on international Greek tourism receipts is huge. The effect on GDP is expected to be unprecedented for a non-war period. Even the economic crisis that hit the Greek economy hard cannot compare with the impact of the Covid-19 on the Greek economy. Tourism receipts reductions are expected to have an impact that ranges from 9 to 14 percent of GDP. And this is the 2020 impact. Unless the uncertainty and risk are eliminated (measured by zero cases in the last 14-days) the tourism impact will continue to exert a big strain on economic resources. Government interventions by spending public money to support household and small business proprietors' income cannot be sustained for a long period of time.

\section{References}

Almond D (2006) Is the 1918 influenza pandemic over? Long-term effect of in utero influenza exposure in the post-1940 U.S. population. Journal of Political Economy 114(4): 672-712.

Bandiera O, Buehren N, Goldstein M, Rasul I, Smurra A (2018) The economic lives of young women in the time of Ebola: lessons from an empowerment program. The Abdul Latif Jameel Poverty Action Lab. Retrieved from: https://bit.ly/3g6g gfk.

Barro RJ, Ursua JF, Weng J (2020) The Coronavirus and the Great Influenza epidemic lessons from the "Spanish Flu" for the Coronavirus's potential effects on mortality and economic activity. AEI Economic Policy Working Paper Series. Retrieved from: https://bit.ly/2ZfVJic.

Brainerd E, Siegler M (2003) The economic effects of the 1918 influenza epidemic. Discussion Paper Series 3791. Centre for Economic Policy Research. Retrieved from: https://bit.ly/3cOlYAg.

Correia S, Luck S, Verner E (2020) Pandemics depress the economy, public health interventions do not: evidence from the 1918 flu. SSRN. Retrieved from: http:// dx.doi.org/10.2139/ssrn.3561560.

Eichenbaum MS, Rebelo S, Trabandt M (2020) The macroeconomics of epidemics. NBER Working Paper 26882. National Bureau of Economic Research. Retrieved from: https://bit.ly/2za61pu.

European Commission (2020a) Tourism and transport in 2020 and beyond. COM (2020) 550. Retrieved from: https://bit.ly/2zMXRmU.

European Commission (2020b) Communication from the Commission: Covid-19 Towards a phased and coordinated approach for restoring freedom of movement and lifting internal border controls. C(2020) 3250 final. Retrieved from: https:// bit.ly/2LESxVh.

European Commission (2020c) Covid-19: guidelines on the progressive restoration of transport services and Connectivity. C(2020) 3139 final. Retrieved from: https:// bit.ly/3bI9sRt.

European Commission (2020d) Commission recommendation of 13.5 .2020 on vouchers offered to passengers and travelers as an alternative to reimbursement for cancelled package travel and transport services in the context of the Covid-19 pandemic. C(2020) 3125 final. Retrieved from: https://bit.ly/3cW2Lgh. 
Fan VY, Jamison DT, Summers LH (2015) The inclusive cost of pandemic influenza risk. NBER Working Paper 22137. The National Bureau of Economic Research. Retrieved from: https://www.nber.org/papers/w22137.

Garret TA (2007) Economic effects of the 1918 influenza pandemic: implications for a modern-day pandemic. Federal Reserve Bank of St. Louis. Retrieved from: https://bit.ly/2zUHHYz.

Hanewald K (2011) Explaining mortality dynamics: the role of macroeconomic fluctuations and cause of death trends. North American Actuarial Journal 15(2): 290-314.

Jones P, Comfort D (2020) The Covid-19 Crisis, Tourism and Sustainable Development. Athens Journal of Tourism 7(2): 75-86.

Jordà Ò, Singh SR, Taylor AM (2020) Longer-run economic consequences of pandemics. Working Paper 2020-09. Federal Reserve Bank of San Francisco. Retrieved from: https://doi.org/10.24148/wp2020-09.

Kalemli-Ozcan S (2002) Does the mortality decline promote economic growth? Journal of Economic Growth 7(4): 411-439.

Ma C, Rogers JH, Xhou S (2020) Global economic and financial effects of $21^{s t}$ century pandemics and epidemics. SSRN. Retrieved from: https://papers.ssrn. com/sol3/papers.cfm?abstract_id=3565646.

Meltzer M, Cox N, Fukunda K (1999) The economic impact of pandemic influenza in the United States: priorities for intervention. Emerging Infectious Diseases 5(5): 659-671.

Niu G, Melenberg B (2014) Trends in mortality decrease and economic growth. Demography 51(5): 1755-1773.

Organisation for Economic Cooperation and Development - OECD (2020) Tackling Coronavirus (Covid-19), contributing to a global effort: tourism responses. Retrieved from: https://bit.ly/3dWP8gM. [Accessed 18 May 2020].

Papanikos GT (2000) The Greek small and medium sized hotel enterprises. Athens: Research Institute of Tourism. (In Greek).

Papanikos GT (2001) Regional analysis of Greek hotels. Athens: Research Institute of Tourism. (In Greek).

Papanikos GT (2002) Employment in the accommodation sector. Athens: Research Institute of Tourism. (In Greek).

Papanikos GT (2005) The Greek tourist receipts. Athens: Research Institute of Tourism. (In Greek).

Papanikos GT (2020) Thucydides and the synchronous pandemic. Athens Journal of History (forthcoming): 1-26. Retrieved from: https://bit.ly/2z9YvLh.

Rasul I (2020) The economics of viral outbreaks. American Economic Association: AEA Papers and Proceedings 110(May): 265-268.

Swift R (2011) The relationship between health and GDP in OECD countries in the very long run. Health Economics 20(3): 306-322.

World Bank (2017) From panic and neglect to investing in health security: financing pandemic preparedness at a national level. Washington, DC: World Bank Group. 



\title{
Understanding the Evolving Roles of Outbound Education Tourism in China: Past, Present, and Future
}

\author{
By Sandy C. Chen ${ }^{*}$
}

\begin{abstract}
This paper discusses the evolving roles of outbound education tourism in China. To provide a thorough understanding, it first surveyed the origins and philosophy of travel as an educational device as well as education travelers' motivations in Chinese history from the first pioneers in the Confucian era to the late 20th century. Then, it described key events and factors that have stimulated the development of the outbound education tourism in modern China and its explosive growth in the $21^{\text {st }}$ century. Through in-depth personal interviews, the study developed a set of measures that reflected present Chinese students' expectations of traveling abroad to study. A follow-up large-scale survey among Chinese students studying in the United States revealed two dimensions underlining these expectations: Intellectual Growth and Lifestyle. The findings of the study have significant implications for key stakeholders of higher education such as administrators, marketers, faculty, staff, and governmental policy-making agencies.
\end{abstract}

Keywords: Education tourism, Outbound tourism, Chinese students, Travel motivation, Expectations.

\section{Introduction}

Traveling abroad to study, which falls under the definition of education tourism by Ritchie et al. (2003), has become a new sensation in China's outbound tourism market. Indeed, since the start of the $21^{\text {st }}$ century, top colleges and universities around the world have found themselves welcoming more and more Chinese students, who are quickly becoming the largest group of international students across campuses. Most of these students are self-financing and pay full tuition and fees, thus every year contributing billions of dollars to destination countries such as the United States, the United Kingdom, Canada, Australia, Germany, France, and Singapore. This single fact, the tremendous financial value, is sufficient in highlighting the importance of this outbound tourism market, which has indeed provoked many destination countries' governments and universities to make favorable policies to attract and admit more Chinese students.

Nevertheless, this market has not received much attention from the perspective of tourism. Although there is growing interest in education tourism in general, much of the existing work discusses such tourism as it pertains to Europe and America. For instance, Brodsky-Porges (1981) traced the roots of Europe's Grand Tour of the $17^{\text {th }}$ and $18^{\text {th }}$ centuries and its impact on society, while Falk et al. (2012) examined Aristotle's three approaches to knowledge, i.e., phronesis

*Associate Professor, Ohio University, USA. 
(theoretical knowledge), techne (skills and crafts), and episteme (practical wisdom), as a framework for understanding how tourism contributes to learning. These Western concepts, however, do not fully explain the Chinese market, which has its own roles reflected in its origins, philosophies, motives, and expectations. This study was thus designed to fill this void. Specifically, the study strived to answer this research question: what roles did education tourism play in different periods in the long history of China?

To achieve this, this study first conducted a background review through describing the origins and philosophy of travel in China as an educational device and evaluated the evolving roles of education tourism from the Confucian era to the late $20^{\text {th }}$ century. Then it summarized key events and factors that had stimulated the development of outbound education tourism in modern China and resulted in its explosive growth in the $21^{\text {st }}$ century. To gain in-depth understanding of the current role of outbound education tourism in China, this study, through empirical data collection, examined the expectations of modern Chinese students who had strong interests in obtaining higher education in a foreign country.

\section{Literature Review}

China has a history of more than five thousand years, in which education tourism has evolved and played different roles in different eras. To understand present day education tourism in China, it is imperative to gain a historical view of this tourism segment to see how culture and historical events in a society have gradually shaped one's beliefs and values. The following text first scans the roles of education tourism in these eras: ancient and imperial times, contemporary era, and modern China. Then it moves to literature review on studies addressing students' expectations.

\section{Ancient and Imperial Times}

The impetus for educational tourism in China in ancient and imperial times was to improve individual knowledge and cultivate personal character. The elites of society, those with education, wealth, or power, traveled within the country to experience different customs and view diverse natural attractions in order to broaden their minds or integrate their own ideas and concepts with literature and reality.

\section{Enrichment of Knowledge and Cultivation of Personal Character}

Tourism in China dates to ancient times, in which travel was considered an integral part of education. Recorded documents show that Kongzi or Master Kong (551-479 BC), who is known as Confucius in the West, and his students were some of China's earliest educational tourists. As described in the ancient texts, in 497 BC, Confucius, followed by his students, left his own country to start a 14year tour covering multiple lands in central Asia. His original motive for this 
endeavor was to share with various rulers his thoughts for managing people through moral values instead of violence. After experiencing great hardships, Confucius was finally welcomed back to his own land. Although few rulers adopted Confucius' views, it was during this long journey that Confucius synthesized his reflections and personal experiences and finally formed his own theories. Many of the scenarios and conversations Confucius had with his students during this journey were later recorded in the Analects, the content of which formed the essence of Chinese culture, while Confucius became the greatest philosopher and educator in Chinese society.

The Master's saying, “Isn't it a pleasure after all to experience frequently what one has learned?" is regarded as the earliest endorsement of the relationship between travel and education. A scan of China's long history shows that this philosophy was practiced widely and repeatedly throughout the generations, including by many highly regarded historical figures whose work and words have been influential in Chinese history.

\section{$\underline{\text { Creation of Outstanding Poems and Essays }}$}

As Mengzi (372-289 BC), known as Mencius in English, said, "To see once is better than to read a hundred times." A principal interpreter of Confucianism, Mencius spent 40 years traveling China to offer advice to rulers about reform. During his travels, he developed his own theories and became another great philosopher in Chinese history. It was during the most prosperous era in Chinese history, the Tang Dynasty (618-907), considered China's Golden Age when the nation was rich, strong, and peaceful, that China produced many highly regarded poets, among them Li Bai (701-762) and $\mathrm{Du} \mathrm{Fu} \mathrm{(712-770),} \mathrm{both} \mathrm{of} \mathrm{whom} \mathrm{traveled}$ extensively and wove their travel experiences into their poems. Some of these have been greatly esteemed from their lifetime to the present in the Chinese cultural area and other parts of the world and were included in the canonical 18thcentury anthology Three Hundred Tang Poems. The popular saying, "To attain wisdom, one must read thousands of books as well as travel thousands of miles," created by a group of elites in this dynasty continues to be included in Chinese textbooks for elementary schools and is one of the most inspirational quotations that encourage people to pursue learning and experience through extensive travel in modern China.

Another influential figure who endorsed the relationship between learning and travel was Su Shi, also known as Dong Po (1037-1101). A Chinese writer, poet, painter, calligrapher, pharmacologist, gastronome, and statesman of the Song Dynasty (960-1279), Su was a major personality of this era and an important figure in Song politics. He was also famed as an essayist, and his prose writings have lucidly contributed to our understanding of $11^{\text {th }}$ century Chinese travel literature on topics such as the contemporaneous Chinese iron industry. His poetry has long been popular and influential in China, Japan, and other nearby areas, and is well known in the English-speaking world through translations by Arthur Waley and others. In talking about the importance of personal experience in learning, $\mathrm{Su}$ asked, "If a person has not experienced a situation but jumps to agree with it, is 
that all right?" Su traveled extensively and wrote of his travel experiences in socalled daytrip essays, which belong to the popular Song literary category of travel literature, the main purpose of which was to use a setting and event to convey a philosophical or moral argument. This writing style was extended and pushed to its peak by Xu Xiake (1587-1641), a Chinese travel writer and geographer of the Ming Dynasty (1368-1644). Xu traveled throughout China for more than 30 years, documenting his travel experiences extensively in his work Xu Xiake's Travel Diaries. These diaries have remained inspirational reading for numerous Chinese. The period from the early 1600s to the mid-1800s, when the Grand Tour was taking place in Europe, coincided with the first half of the Qing Dynasty (16441911) in Chinese history, when China again experienced a period of relative peace and prosperity and elites of the society were free to travel throughout the country for learning and writing purposes.

\section{Contemporary Era}

The education tourism in the contemporary era of China has played different roles, which could be observed in several distinct characteristics. First, it has expanded "outbound." That is, Chinese young people traveled to more advanced countries, especially those countries that were stronger than China. Secondly, the educational travelers were focused on learning about subjects, such as economy, military, science, and politics, that might strengthen China as an independent country. Thirdly, outbound educational tourism activities were limited to a minority of people who were considered the elites of the society and who were either selected and supported by the government or could afford to volunteer with their own resources. And finally, these educational travelers were all motivated by the same goal, "to seek the right path to advance China" in turbulent times.

\section{$\underline{\text { Path to Peace }}$}

As shown in contemporary history texts, it was during the Qing Dynasty that China began experiencing more contact with the rest of the world, Europeans in particular, beginning with the Portuguese in the mid-16th century. But unhappy with the restrictions imposed by China on trade with foreigners, Europeans pressed for more access, and by the $18^{\text {th }}$ century the key they were using to open Chinese doors was opium. Despite Chinese government prohibitions, Britain continued to increase imports of this commodity into China throughout the $18^{\text {th }}$ and into the $19^{\text {th }}$ centuries, leading to addiction by millions of people and the draining of silver from the Chinese economy. Finally, in response, the Chinese government ordered the confiscation of all opium and a halt to further imports; this in turn set off the Opium Wars (1839-1842, 1856-1860) with Britain and later France. China's eventual defeat and humiliation in these wars at the hands of European powers marked the start of a massive invasion of Western products and ideas into the Chinese market.

In response to its losses, the Chinese government undertook a series of reforms amounting to a Western-style industrialization movement, also known as 
the Self-Strengthening Movement, which among other reforms initiated outbound educational tourism. As Zhang and Liu (2005) have described, this era was marked by five waves of studying abroad, each of which reflected the unique characteristics of the corresponding period. The first wave occurred between 1872 and 1896, during which the Chinese government sent more than 200 bright adolescents to France, Germany, Britain, and other European countries to study advanced natural science, military technology, and other subjects. The slogan for this wave was that "to be strong, Chinese must learn advanced knowledge and technology" (Zhang and Liu 2005).

The second wave began in 1901 after China's defeat in the first Sino-Japanese War (1894-1895), followed by a violent reaction against foreign influence known as the Boxer Rebellion (1897-1901) and military intervention by the West to put it down. As China came to realize, its neighbor Japan was far ahead in acquiring new knowledge and technology, and was a much more convenient and inexpensive destination for Chinese young people to extend their learning rather than traveling far away to Europe. As a result, over the next several years, thousands of Chinese traveled to Japan to study many subjects, military technology in particular (Zhang and Liu 2005). This educational wave, however, made the Americans uneasy. In their eyes, Japan's influence on Chinese students put the US in a less favorable position as becoming a world leader. Therefore, in 1908 the U.S. Congress passed a bill returning half of China's compensation to the US for the Boxer Rebellion to help pay expenses for Chinese students to study in America. This ultimately led to the third wave of educational tourism beginning in 1911, as Chinese students traveled to the US to study such subjects as engineering, agriculture, medicine, physics, chemistry, and business management, which were considered important for advancing China's economy and society (Zhang and Liu 2005).

The fourth wave of educational tourism was greatly influenced by several major events, including the Chinese Revolution of 1911 that overthrew the last emperor and ushered in modern China, the start of World War I in 1914, the New Culture Movement that began in China in 1915, and the Russian Revolution in 1917 (Zhang and Liu 2005). In this wave, working and studying in France became a trend in the early 1910s among young people who were greatly influenced by the works of Karl Marx and who aggressively sought the best future for China. For the same reason, the 1920s were marked by the fifth wave of educational tourism, as patriotic Chinese were sent to Russia to study the Russian model of establishing a strong nation based on the working class. This wave, however, was soon interrupted by the Chinese Civil War (1927-1950) and World War II (Zhang and Liu 2005).

\section{New China}

Outbound educational tourism development in the People's Republic of China (also called "New China"), which was formed in 1949 by the victorious Communist Party after the Civil War, can be divided into two distinct periods. The first period, from 1949 to 1999, showed that outbound educational travel primarily 
served politics. The second period, starting at the turn of the new millennium, showed that outbound educational tourism was a by-product of leisure tourism.

\section{$\underline{\text { Transitioning from Political Means to Leisure }}$}

After the Chinese Communist Party assumed leadership of the country in 1949, some limited educational tourism occurred for a short period during which the new Chinese government sent a number of compatriots to the Soviet Union to study both technology and theories of communism. But this ceased in the late 1950s when the relationship between the two countries grew strained. Indeed, from that time tourism itself completely disappeared in China until the late 1970s, when the government decided to shift its focus from politics to economic reform. At that time some people were sent abroad to acquire advanced knowledge in various fields. Eventually in the early 1990s, studying overseas to achieve a better life became something of a fad among the country's young people, but the high obstacles of obtaining a private passport, visa, and financial support gave opportunities only to those who were considered outstanding and who scored high enough on all kinds of exams. This would enable them to secure scholarships from graduate schools in other countries. A majority of these students finished their undergraduate studies in China and continued on to a foreign country for a master's or doctoral degree. Most of the students who were not sent by the government chose to remain permanently abroad after finishing their studies, mainly for the greater opportunities for a better life. As the new millennium approached, however, this picture had undergone a complete change.

\section{Explosion of Outbound Educational Tourism}

Entering the $21^{\text {st }}$ century, the outbound educational tourism market in China was starting to reveal a very different landscape; indeed, the changes indicated not simply a revitalization but a revolution in the market. As Education Online (Eol.cn 2012) reported, the number of students traveling abroad to study suddenly rose in 2000 and has since continued growing at an average rate of about $20 \%$ a year. In 2012 , more than 400,000 students obtained visas and traveled to a foreign country to study, while the cumulative number of Chinese students studying overseas between 1978 and 2012 approached 2 million (Eol.cn 2012). As the Canadian newspaper The Globe and Mail (2008) and the Australian newspaper the Daily Telegraph (2013) have reported, this trend will increase over the next 10 years, so that by 2020, more than 600 million Chinese are expected to achieve middle class status, with the money and the ambition to obtain for their children an education with foreign-label cachet. The Daily Telegraph (2013) reported that HSBC had recently conducted a survey of 1000 Chinese respondents. The survey found that $68 \%$ indicated an intention to send their children overseas to study in the next 5 to 10 years.

As further reported in large media such as the South Morning China Post (2013), USA Today (2013), and the International Herald Tribune (2013) in the past 10 years Chinese students have made up the largest overseas group in their 
top 10 study destinations. Other countries included the US, Australia, Japan, Great Britain, South Korea, Canada, Singapore, France, Germany, and Russia. Thus, Chinese students have become a major driving force behind the explosive growth in outbound educational tourism in the $21^{\text {st }}$ century tourism industry.

Another noticeable change in China's outbound educational tourism has been a demographic shift. Before the turn of the new millennium, the market was dominated by older students seeking postgraduate degrees. Most of these were described as the brightest young people in China who went overseas with partial or full scholarships. But since then, this picture has changed. In 2001, $90 \%$ of outbound students were self-financing, and by 2012 more than $93 \%$ of students were self-funding their own studies overseas (Eol.cn 2012). The academic structure has also changed, such that more than half of overseas students are pursuing undergraduate studies or high school education. This also means that the average age of this market has become much younger while the economic contributions to the destination countries are higher. Currently, the Chinese outbound student market makes up s an annually increasing multiple-billion dollar business to each of the top education export countries in the world (e.g. Daily South Morning China Post 2013, USA Today 2013, The International Herald Tribune 2013).

The biggest revolution taking place in this market, however, is its increasing diversity. That is, this market is no longer dominated by students who travel abroad to study specifically for a college degree. The number of students who travel overseas to attend study camps during summer and winter break has also boomed. These camps last anywhere from 10 days to 1 month, during which students take courses, participate in school activities, live with local families, travel to major attraction sites, visit top university campuses, and so on in the destination country. Most of these students are high school and college students who want to check out the place they might be attending for an undergraduate or postgraduate degree. As reported by USA Today (2013), "US summer camps are increasingly popular in countries such as China, where [a] rising middle class can send their children to experience American life - and possibly set the stage for going to college in the USA."

Another new sector consists of students who obtain overseas internships. Since the turn of the $21^{\text {st }}$ century, study, work, and travel (SWT) programs have become popular among current college and graduate students in China, inspired in part by the US Mutual Educational and Cultural Exchange Act of 1961 (better known as the Fulbright-Hays Act), which according to its preamble sought "to increase mutual understanding between the people of the United States and the people of other countries by means of educational and cultural exchanges." The size of this sector is relatively small, but is growing as fast as the others.

Indeed, through all Chinese history, the Chinese government has never been as open as it is today in granting permission to its average citizens to travel overseas; and the Chinese society has shown much harmony, peace and stability since the creation of New China. All these have resulted in the prosperity of the nation's leisure tourism, which used to be either a "forbidden" activity for the public or a "luxury" activity only for a minority of people. Leisure travel in New 
China has greatly enhanced Chinese people's knowledge and understanding of other countries. With increasing disposable incomes, Chinese families, many of whom have only a single child as a result of the Chinese government's one-child policy, do not hesitate to send their children to countries they believe offer highquality education that will make these young people internationally competitive in the future job market.

Nevertheless, some people partially credit the fast growth in overseas education tourism to the overly strict and stressful national college entrance exam (International Herald Tribune 2011). As of 1977, when formal admission to college through the open National College Entrance Examination was resumed in China, students in China's test-centric culture spend most of their high school years studying for the exam, which is the sole determining factor in whether a high school graduate will be accepted by one of the nation's oversubscribed universities. With more financial resources as well as the new freedom to travel abroad, now more and more parents let their children skip this exam and send them to colleges in foreign countries. As InsideHigherEd (2013) reported, 1.4 million high school students in China skipped the national entrance exam in 2012; and among those students, more than $20 \%$ went directly to foreign colleges. It predicted that more high school students will bypass the exam in the coming decade and will travel abroad to further their education.

And of course, technology, the Internet in particular, has added tremendous fuel to this market. This is an important issue concerning China, where all websites are under strict censorship by the government. Because the government considers educational websites "clean," its people have free access to them and can explore their options. Media such as color photos and video clips on the Internet make tangible what they have read and heard about Western education, culture, and society, thus greatly stimulating their desire to travel abroad to experience it all.

The ultimate impetus behind outbound travel can be explained by Chinese parents' strong belief in the value of education. For the average Chinese, attending college has long been an official way to change a family's status. A college degree, especially one obtained from an advanced country, means good job opportunities and a path to success. For elite families, a college degree from an "Ivy leaguelevel" school in the world is an important symbol. Studying abroad helps fulfill the Chinese ancient maxim that to attain wisdom, a person must read thousands of books and travel thousands of miles, and no doubt helps realize every Chinese parent's dream for their child by integrating education and learning through travel. In addition, to many Chinese parents, the Western teaching style seems more relaxed and more focused on developing practical knowledge and skills than on taking tests, and so is appealing to those who work hard to give their children a good life.

Together, these factors have apparently created fertile ground for the growth of China's outbound education tourism, such that the practice of middle-class families sending their children abroad as part of their education has become pervasive. Some questions then naturally arise: what do these young, middle-class student-tourists themselves think about traveling abroad to study, something their parents never did? Do their expectations differ from those of previous generations 
of educational outbound tourists in China's history? How do these expectations compare with Western philosophies of travel as a learning device?

\section{Outbound Tourism and Chinese Students' Expectations}

Inquiry into these questions is meaningful since it could help all stakeholders gain a better understanding of this group of travelers by looking at this fastgrowing market through a different lens to sustain its economic value. From a business perspective, addressing these questions, particularly students' own expectations of studying abroad is important since it is the first step in understanding their satisfaction with a host educational institution. In marketing, as elaborated by many researchers (Parasuraman et al. 1985, Brown sand Swartz 1989, Saleh and Ryan 1991, Thompson and Yarnold 1995), satisfaction occurs when a customer's perceptions (i.e., actual experience) meets his or her expectations (i.e., anticipated experience), which is referred to as confirmation. The greatest satisfaction occurs when the customer's perceptions exceed his or her expectations; this is referred to as positive disconfirmation. Dissatisfaction occurs when a negative discrepancy is present between the customer's perceptions and expectations; this is referred to as negative disconfirmation.

Based on the Service Quality Gap Model of Parasuraman et al. (1985) in business, customer satisfaction is determined by the magnitude and direction of the gap between customer expectations and perceptions of product or seller performance (Parasuraman et al. 1985, Brown and Swartz 1989). The main sources for the formation of customer expectations, as Parasuraman et al. (1985) identified, include a customer's past experiences, both direct and indirect; personal characteristics (e.g., consumption philosophy, personal needs, etc.); external company communications (e.g., advertising, media releases, etc.); and word-ofmouth (e.g., friends, consumer reports, consultants, etc.).

Chinese students' expectations of studying in a foreign university seem to come from all five main sources: parental influence, past experiences, personal characteristics, external communications, and word-of-mouth. As an embedded part of the Chinese culture, parents have much to say about their children's lives. Going to college either in China or overseas is more of a parent's decision than the student's, as parents transfer their expectations of studying overseas to their children. Some students are lucky enough to participate in the decision-making process. Both parents and students are influenced by enormous promotional messages via multiple channels, such as websites, smart phones, TV, newspapers, radio, friends, relatives, teachers, and online cell phone chat rooms. To gain firsthand information about modern Chinese students' own opinions about studying abroad, this study used a mixed method of data collection: first, an in-depth interview, followed by a large-scale survey. 


\section{Research Methods}

The empirical data collection in this study was composed of two stages. Since the measurements of Chinese student expectations of study abroad were not readily available in the literature, this study first applied the grounded theory (Glaser and Strauss 1967) and designed a qualitative research procedure focusing on collection of interview data to develop the expectation measurement. A questionnaire containing these "student expectation" measures was developed and administered to a group of Chinese students who were attending a large public university located in the Midwestern US. Then, principal factor analysis was used to identify the underlying dimensions of student expectations. The following text articulated these data collection and analysis activities.

Taking an inductive approach, this study first conducted in-depth interviews, online or offline, with 34 high school students in China during the summer break in 2014. All the interviews followed the principle of open sampling, described by Strauss and Corbin (1990) as "sampling those persons, places, and situations that will provide the greatest opportunity to gather the most relevant data about the phenomenon under investigation" (p. 181). The interviewees were recruited using snowball sampling or respondent-driven sampling with all the participants recommended by high school teachers and parents.

The average age of the interviewees was 18 years. The youngest age was 16 and the oldest was 24. There were more females (around 56\%) than males. Most were attending high school, ranging from the first to the third years. All expressed interest in someday studying abroad to get a college degree; $65 \%$ would like to join a summer or winter camp before going to college, while $62 \%$ would like to do an internship abroad before landing a full-time job. Approximately $88 \%$ said that their families would pay for their college education, but some wished to be sent abroad by the Chinese government, while a small number were uncertain about their financial resources for college. The content analysis identified patterns, key words, and themes among students' responses regarding their expectations of study abroad. This resulted in 20 expectation themes, which reflected both the students' expectations of themselves and their host communities and universities.

\section{Survey and Findings}

A survey was then designed by using the expectation statements generated through the in-depth interviews. The online data collection website, SurveyMonkey, was used to distribute the survey. From February 26 to March 6, 2016, an invitation and several reminders were sent to more than 200 Chinese students who were studying at a large public university in the Midwestern US and whose contact information was recorded in a database by the university's Chinese Student Association. The university's fact sheet showed that more than 500 Chinese students were enrolled in a variety of disciplines at the time the survey was administered. More than 80 students filled out the survey, and 76 complete responses were usable, resulting in a response rate of $38 \%$. 


\section{Characteristics of Respondents}

Statistics show that the respondents came from 34 majors. At the survey time, more than $53 \%$ of them were undergraduate students, approximately $39 \%$ were graduate students, more than $5 \%$ were English as a Second Language (ESL) students, and the rest were exchange students. The average age of the respondents was 24.61 (median age 24.50, mode 24). The youngest respondent was 19 years old, while the oldest was 31 . Most of the students, as many as $79.5 \%$, said their studies in the United States were fully or partially funded by their families, with the rest funded by different sources, including scholarships and self. There were more female $(58.67 \%)$ than male respondents. All the respondents had been in the United States at least 6 months; the average duration of studying in the country was 40 months (i.e., more than 3 years); the maximum was 106 months (more than 8 years), indicating that some of the respondents might have completed their high school education in the United States.

\section{$\underline{\text { Principal Factor Analysis }}$}

A principle factor analysis was performed on all the expectation statements to reduce items and identify the underlying dimensions. A varimax rotation with a factor loading of 0.5 or higher was used. The value for Kaiser-Meyer-Olkin Measure of Sampling Adequacy was 0.91; the Chi-Square value is 885.20 (df = $76, \mathrm{p}<0.000$ ) for the Bartlett's Test of Sphericity, indicating the suitability of the collected data for the principal factor analysis. The number of factors to be extracted was determined by evaluating the screen plot and the eigenvalue scores. The latent root criterion of 1.0 was utilized for the factor extraction. Two factors were extracted from the expectation statements, accounting for $76.40 \%$ of the variance. A reliability analysis was performed to further refine the factors. These factors, the items loading on them, and the commonality are reported in Table 1. The factors were labeled based on highly loaded items and the common characteristics of the items they included. Factor 1 included 10 measures indicating respondents' expectations of learning new knowledge, cultures, customs, and English and was labeled Intellectual Growth. This factor explained more than 51\% of the total variance. The reliability test of all the measures showed an alpha value of 0.971 . Factor 2 included measures indicating students' expectations to meet good-looking people, to have freedom, and to live in the United States and was labeled American Lifestyle. This factor explained more than $25 \%$ of the total variance. The reliability alpha value was 0.862 . An individual-item analysis indicated that all statements in each of the factors should remain. 
Table 1. Principle Component Analysis of Expectation Statements

\begin{tabular}{|l|c|c|c|}
\hline Factor & \multicolumn{2}{|c|}{ Loading } & Commonality \\
\hline Factor 1 Intellectual Growth (I...) & & & \\
\hline $\begin{array}{l}\text { expected to broaden my mind and } \\
\text { horizon }\end{array}$ & 0.877 & & 0.828 \\
\hline $\begin{array}{l}\text { expected to learn about different } \\
\text { cultures and customs }\end{array}$ & 0.876 & & 0.811 \\
\hline expected to enrich life experience & 0.873 & & 0.805 \\
\hline $\begin{array}{l}\text { expected to challenge and develop } \\
\text { myself }\end{array}$ & 0.848 & & 0.802 \\
\hline $\begin{array}{l}\text { expected to prepare myself for the } \\
\text { competitive job market }\end{array}$ & 0.801 & & 0.779 \\
\hline $\begin{array}{l}\text { expected to learn advanced knowledge } \\
\text { and technology }\end{array}$ & 0.785 & & 0.769 \\
\hline $\begin{array}{l}\text { expected to fulfill my curiosity about } \\
\text { different lifestyles }\end{array}$ & 0.731 & & 0.764 \\
\hline expected to learn English & 0.625 & & 0.736 \\
\hline Factor 2 American Lifestyle (I...) & & & 0.731 \\
\hline expected to meet good-looking people & & 0.881 & 0.729 \\
\hline expected to have freedom & & 0.823 & 0.622 \\
\hline $\begin{array}{l}\text { expected to have the possibility of living } \\
\text { in the USA }\end{array}$ & & 0.809 & \\
\hline No. of Items & 8.971 & 0.862 & \\
\hline Alpha value ( $\alpha$ ) & 51.164 & 25.234 & \\
\hline Eigenvalue & & 76.393 & \\
\hline$\%$ of Total Variance & & & \\
\hline Total variance (\%) & & & \\
\hline Na all ste & & & \\
\hline
\end{tabular}

Note: all the statements were placed on a 7-point Likert scale, as "1" referring to "strongly disagree" and "7" referring to "strongly agree." Factor analysis rotation method - Varimax with Kaiser Normalization. Rotation converged in 3 iterations. Kaiser-Meyer-Olkin Measure of Sampling Adequacy is 0.91; In Bartlett's Test of Sphericity, the Chi-Square value is 885.20 ( $\mathrm{df}=76, \mathrm{p}<$ 0.000 ).

\section{Summary of Evolving Roles of Outbound Education Tourism}

As part of the research project that was conducted in response to the phenomenal growth in education tourism as a viable outbound tourism segment in China, this study evaluated and reviewed relevant literature information published in both Chinese and English. The study surveyed the evolving roles of education tourism, including its origins and philosophies as well as educational travelers' expectations and motives throughout China's history from the Confucian era to China today. Table 2 presents a summary view of the evolving roles of outbound education tourism in China. 
Table 2. Evolving Roles of Outbound Education Tourism in China

\begin{tabular}{|c|c|c|}
\hline Timeline & Role & Information Source \\
\hline $\begin{array}{l}\text { Ancient and Imperial } \\
\text { Times }\end{array}$ & $\begin{array}{c}\text { Enrichment of knowledge } \\
\text { and cultivation of personal } \\
\text { character } \\
\text { Creation of outstanding } \\
\text { poems and essays }\end{array}$ & $\begin{array}{l}\text { History books, ancient } \\
\text { literature such as essays, } \\
\text { poems, and famous quotes }\end{array}$ \\
\hline Contemporary Era & - $\quad$ Path to peace & $\begin{array}{c}\text { History books, ancient } \\
\text { literature such as essays, } \\
\text { poems, and famous quotes }\end{array}$ \\
\hline $\begin{array}{l}\text { New China } \\
\text { before the } 21^{\text {st }} \text { century }\end{array}$ & $\begin{array}{ll}\text { - } & \text { Political means } \\
\text { - } & \text { Leisure }\end{array}$ & $\begin{array}{l}\text { History books, ancient } \\
\text { literature such as essays, } \\
\text { poems, and academic } \\
\text { publications }\end{array}$ \\
\hline $\begin{array}{l}\text { New China } \\
\text { the } 21^{\text {st }} \text { century }\end{array}$ & $\begin{array}{cc}- & \text { Intellectual growth } \\
- & \text { Foreign lifestyles } \\
\end{array}$ & $\begin{array}{l}\text { In-depth interview and } \\
\text { survey }\end{array}$ \\
\hline
\end{tabular}

This resulted in several significant findings. First, throughout the long history of China, traveling played a significant role in Chinese people's acquisition of new knowledge, cultivation of personal character, and inspiration in creating outstanding literature. In turbulent times during which China was invaded by other countries, traveling abroad became a path for Chinese patriots to seek ways to build up a strong and peaceful country. However, in the PR China, i.e., New China, traveling abroad in the $21^{\text {st }}$ century to study has taken on a dramatically different connotation. Through in-depth interviews, the study revealed a set of measures reflecting the expectations of current Chinese students in traveling abroad to study. The quantitative study identified two dimensions underlining these expectations: Intellectual Growth and American Lifestyle.

\section{Implications and Contributions}

These findings have multiple implications. First and most importantly, it offers both academics and practitioners a view of the origins and history of educational tourism in China, which in turn explains the deeply rooted motivation for young Chinese people today to explore the world. Specifically, international academics engaging in studies of Chinese educational tourists can use this information to develop learning activities and course structures suitable for a Chinese audience. Since tourism marketers are eager to embrace this market as well, they can apply these background factors to effectively refine marketing and service strategies and to sustain the long-term success in this market. This paper presents an urgent call to the Chinese government for establishing relevant policies and regulations, which were very limited at the time of this article's composition, to guide the market growth and to protect their own young citizens studying abroad. This paper also dismisses such claims as "almost all Chinese scholars are spies" (Redden 2018) by some western governments. The findings of this study 
confirm a significant role of outbound educational tourism: a way to give best education to students learning, to enhance knowledge, and to promote understanding of diverse cultures.

This paper makes several significant contributions. First and most important, it adds new value to the literature pertinent to educational tourism by developing a measurement scale of Chinese student expectations of studying abroad. It also offers both academics and practitioners a practical view on how they can develop practical learning activities and course structures suitable for a Chinese audience. Since tourism marketers are eager to embrace this market, they could also use the new information to effectively refine marketing and service strategies to sustain long-term success in this market.

\section{Limitations and Future Studies}

The study has several limitations which require the reader's attention. First, given the long history of China, the background information on education tourism development was relatively brief. Second, the low response rate of the survey was not surprising but limited more sophisticated data analysis. Third, the survey did not include those Chinese students who were not actively involved in Chinese students' associations at the target universities. The surveyed students all originated from Mainland China, and their views may differ from Chinese students originally from other parts of the world. Finally, the survey was conducted among Chinese students studying in the United States only and they might not share the same underlying expectations of those studying in other countries.

Nevertheless, this study presents a good foundation for future studies in outbound education tourism, particularly Chinese students' satisfaction level with their host universities: the expectation measures could be used as "correspondent perceptions" and the difference between one's expectation and perception is a good indicator of satisfaction. This is the first and critical step for host universities that target Chinese students to sustain and expand their current Chinese market share. In addition, another round of empirical data collection with more rigorous sampling could be collected to identify and validate the underlying dimensions that reflect the specific expectations of current students in traveling abroad to study. The origins and history of education tourism in different countries can be compared to reveal cultural differences and similarities.

\section{References}

Brodsky-Porges E (1981) The grand tour: travel as an educational device 1600-1800. Annals of Tourism Research VIII(2): 71-186.

Brown SW, Swartz TA (1989) A gap analysis of professional service quality. Journal of Marketing 53(2): 92-98.

Daily Telegraph (2013) Chinese like our schools. Local 33, June 21. Australia.

Eol.cn (2012) An investigation of China's study-abroad market. Retrieved from www.eol.cn. [Accessed: November 19, 2012]. 
Falk JH, Roy B, Jan P, Pierre B (2012) Travel and learning: a neglected tourism research area. Annals of Tourism Research 39(2): 908-927.

Glaser B, Anselm LS (1967) The discovery of grounded theory. Chicago, IL: Aldine.

Globe and Mail (2008) Cashing in on China's thirst for university training. Report on Business Column-Education: B9. Canada: Vancouver. June 11, 2008.

InsideHigherEd (2013) Eyeing universities abroad, Chinese students skip Gaokao. Retrieved from www.insidehigheredu.com. [Accessed: June 10, 2013].

International Herald Tribune (2013) Dreams cut short for 2 Chinese teenagers; students killed in crash had hoped for summer of American experiences. News 4. July 9, 2013.

Parasuraman A, Zeithaml VA, Berry LL (1985) A conceptual model of service quality and its implications for future research. Journal of Marketing 49(Fall): 41-50.

Redden E (2018) Did Trump call most Chinese students spies? Higher Education News. Retrieved from URL: https://bit.ly/39NR8qk. [Accessed: September 8, 2018].

Ritchie BW, Neil C, Christopher PC (2003) Managing educational tourism. Clevedon: Channel View Publications.

Saleh F, Ryan C (1991) Analyzing service quality in the hospitality industry using the SERVQUAL model. The Service Industries Journal 11(3): 324-343.

South Morning China Post (2013) Study horizons widen; overseas learning has numerous merit. Supplements 10. China: Hong-Kong. July 15, 2013.

Strauss A, Corbin L (1990) Basics of grounded theory methods. Beverly Hills, CA: Sage.

Thompson DA, Yarnold PR (1995) Relating patient satisfaction to waiting time perceptions and expectations: the disconfirmation paradigm. Academic Emergency Medicine 2(12): 1057-1062.

USA Today (2013) Study tours of U.S. increasingly popular overseas; students test out schools, visit multiple campuses across nation. News 3A. July 9, 2013.

Zhang CL, Liu R (2005) China's contemporary study abroad, its trend, studying subjects, and analysis of its historical meaning. Higher Education on Science 4(62): 30-69. 



\title{
Is YouTube Advertising Effective: Context of Travel Industry?
}

\author{
By Elmira Djafarova* \& Kristina Kramer ${ }^{ \pm}$
}

\begin{abstract}
The tourism industry was identified as one of the industries with the highest expenditures on online advertising and experienced major changes through the rise of social media. The purpose of this study is to evaluate the effectiveness of YouTube advertising in the context of the tourism. 15 faceto-face interviews were conducted to collect primary data. These research findings suggest to use YouTube advertising when the objective is to create brand awareness or remind customers of a product. YouTube advertising is less suitable for advertising objectives focusing on persuading tourism customers to purchase.
\end{abstract}

Keywords: advertising effectiveness, tourism, Trivago, YouTube

\section{Introduction}

The opportunities offered by online advertising are used by multiple industries but to different extents. After finance and retail, the travel and tourism industry is the sector with the highest expenditures on online advertising (Faith 2014). Especially meta search engines such as Trivago and Kayak as well as hotel chains like Marriott are heavily investing into online advertising (Wordstream 2011). Social media is one of the "two mega trends" (Xiang and Gretzel 2010) influencing the tourism system and has major impacts on the consumer decisionmaking process. Especially within the stage of information search, its influence is considered as particularly strong (Xiang and Gretzel 2010). Thus, social media channels are an essential part of many touristic organisations' advertising strategy. However, major companies such as Trivago are facing low returns on advertising spend. In the first nine months of 2016, Trivago spent $\$ 562.1$ million on advertising, however, its return on advertising spend is with $116.1 \%$ relatively low and contributed to the company's net loss of $\$ 53$ million in the first nine months of 2016 (Jhons, 2016). For the organisation and the industry as a whole, YouTube is a major advertising channel as consumers are increasingly searching for travelrelated content on YouTube (Crowel et al. 2014). As previous research did not assess the effectiveness of YouTube for specific products or industries, this study analyses how effective YouTube advertising is with the example of Trivago and identifies wider implications for the tourism industry.

Having a large user base of over one billion active users (YouTube 2017) and offering a wide range of advertising formats, YouTube is considered as highly

\footnotetext{
*Principal Lecturer, Northumbria University, UK.

${ }^{ \pm}$Former Research Student, Newcastle Business School, Northumbria University, UK.
} 
effective in terms of engaging existing audiences, reaching new audiences (Rohrs 2014), building brand awareness and promoting products via advertising (Miller 2011). A major form of advertising on YouTube are so-called 'in-stream video advertisements': audio-visual video advertisements placed within YouTube videos which are considered as particularly effective due to their high degree of attention demanded.

YouTube seems promising and is strongly promoted by Google, it is also criticised for providing mostly lower value user generated content (UGC) and not being able to provide a top-quality entertainment context for advertisements as traditional channels such as television do (Shields 2016). Social networking sites such as Facebook, Instagram, Pinterest, Twitter and Snapchat provide increasingly competing opportunities for online video advertisements (LePage 2016). According to eMarketer (2016a), YouTube will be able to maintain its market share throughout 2017 but will face a downward trend due to this competition. Lastly, online advertising is also often perceived as irritating (Ibrahim 2013) and can lead to negative views of the advertised brand (Smith 2012).

\section{Literature Review}

\section{How Tourism Uses Social Media for Advertising}

The rise of social media has led to fundamental changes in business-tobusiness, business-to-consumer and consumer-to-consumer communications (Leung et al. 2013). Particularly the tourism industry has been affected by this development and experienced major impacts of social media on the consumer decision-making process, promotion and interaction with consumers (Hudson and Thal 2013, Zeng and Gerritsen 2014). Xiang and Gretzel (2010) identified the developments within social media and search engines as the "two mega trends" ( $p$. 179) that significantly influence the tourism system. Although social media is considered to affect all stages of the tourist's decision-making process (Leung et al. 2013), its influence is considered as particularly strong within the stage of information search (Xiang and Gretzel 2010). According to Leung et al. (2013), significant amounts of travel information are collected and reviewed by travellers on social media early in the decision-making process as tourism-related products and services are highly priced, differentiated and, thus, require high involvement. One of the most important information sources is reviews and experiences shared by other consumers, which are referred to as eWOM and UGC in the context of social media (Leung et al. 2013). EWOM is considered as highly trustworthy by consumers due to the lack of commercial self-interest of the publisher and tends to be more influential than commercial sources (Leung et al. 2013). Hence, multiple studies have researched the impact of UGC or eWOM on early stages of the consumer decision-making process within the tourism industry (e.g., Ayeh et al. 2013, Cox et al. 2009, Manap and Adzharuin, 2013).

In terms of advertising, Fotis et al. (2012) state that leveraging social media to market tourism products has shown to be an excellent strategy. Leung et al. (2013) 
outline the significance of blogs as a promotional tool within the tourism industry due to the opportunity of creating lively and credible content and connecting organisations with their customers. YouTube is also considered as an important promotional tool for tourism organisations as users can be provided with audiovisual content of destinations and accommodations (Reino and Hay 2016). Currently, there is only one study that examines the use of YouTube in tourism. However, it focuses on the role of visual UGC on YouTube for creating destination images (Reino and Hay 2016). Within the study, 320 tourism videos uploaded to YouTube by individuals and destination marketing offices have been analysed. Major findings included that YouTube is a strong tool to shape a destination's image (Reino and Hay 2016). However, the various stakeholders involved in tourism are still struggling to use its full potential (Reino and Hay 2016). Moreover, Reino and Hay (2016) state that YouTube is a useful tool for the accommodation sector to publish promotional videos. Nevertheless, no research has been conducted yet to evaluate the effectiveness of advertising on YouTube within the tourism industry. Moreover, previous research regarding advertising effectiveness within tourism focused mainly on destinations (e.g., Pratt et al. 2010, Shani et al. 2010).

YouTube offers organisations a wide range of advertising opportunities, segmented into in-stream video and in-video advertisements (Dehghani et al. 2016). In-stream advertisements are integrated into the video and can be further distinguished by their position within the video: Pre-roll advertisements are shown before the video, mid-roll advertisements during the video and post-roll advertisements are placed at the end of the video ( $\mathrm{Li}$ and Lo 2015). The purpose of in-stream advertisements is to attract attention by interrupting the video a user would like to watch. Thus, the main characteristic of in-stream advertisements is the difficulty to ignore them ( $\mathrm{Li}$ and Lo 2015). However, advertisers can also choose whether the advertisement can be skipped to reduce the degree of intrusiveness (YouTube 2012). In-video advertisements are less intrusive, mostly static overlay advertisements that appear on the bottom of the YouTube video player. If desired, the user can minimise or close these advertisements (Dehghani et al. 2016).

Advertisements on YouTube can be targeted by geographic and demographic criteria or via topics (YouTube 2012). Due to the platform's user demographics, YouTube advertising is considered as particular effective among younger target audiences. The majority of YouTube users is between 25 and 34 years old, followed by the age groups from 35 to 44 and 18 to 24 years (Blattberg 2015). Regarding their educational background, YouTube users are more likely to have a college degree or a comparable qualification than the general population (Nielsen 2016). In terms of geographic origin, the largest share of YouTube users is based in the United States of America, followed by Brazil, Russia, Japan, India, the United Kingdom, Germany, France, Mexico and Turkey (Statista 2016). Males and females are equally active on YouTube (Nielsen 2016). 


\section{Evaluating Advertising Effectiveness}

Traditional measures of advertising effectiveness remain relevant in the context of interactive advertisements as the consumers' response is similar to traditional media (Pavlou and Stewart 2000). However, Pavlou and Stewart (2000) also emphasise the need of incorporating the consumers' interaction with an advertisement when assessing the effectiveness of online advertising instead of merely assessing their response to it.

Considering this new paradigm, Martin-Santana and Beerli-Palacio (2012) distinguish between three types of measuring advertising effectiveness. According to Martin-Santana and Beerli-Palacio (2012), the most commonly used cognitive measurements are memory-based techniques such as aided and unaided brand recall and recognition. Affective measurements include aspects such as the liking and attitude towards an advertisement and the advertised brand (Martin-Santana and Beerli-Palacio 2012). Within the advertising response model, Metha (1994) identified a positive relationship between the processing of an advertisement and the development of an attitude towards the advertised brand, which then influences the purchase interest and intention. This model is complemented by Hwang, Yoon and Park (2011) who found that the processing of an online advertisement influences the attitude towards the website, the advertised brand and the purchase intention (Figure 1).

Figure 1. Research Model (Adapted from Hwang et al. 2011, p. 900)

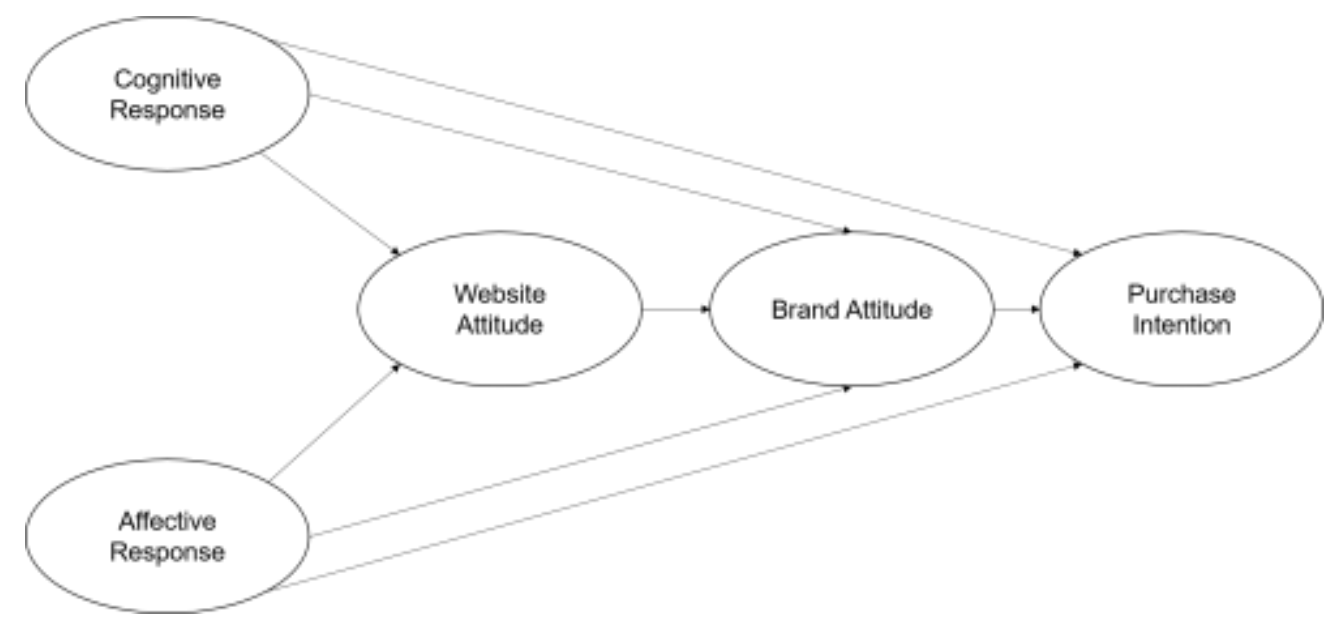

The last set of metrics is represented by conative measurements, which emerged through the interactivity of online advertising. Martin-Santana and Beerli-Palacio (2012) state that the click-through rate (CTR) is the "most widelyused conative measurement of online effectiveness" (p. 423). Click-through occur when users click on an advertisement and are transferred to the advertiser's website (Chatterjee 2001). The CTR describes the ratio between the number of users who have seen an advertisement and the number of those who have clicked it (Rosenkrans 2009). It is widely discussed whether CTR is an effective indicator for measuring online advertising effectiveness. Although it measures a direct 
response to the advertisement and is easily tracked, Chandon et al. (2003) argue that CTR measures only short-term effects and neglects the aspect that the advertisement can also have an impact on the user when it is not clicked on.

An important aspect of an online video advertisement's format is its length. YouTube offers in-stream advertisements at lengths of 15, 30 and 60 seconds or longer (YouTube 2012). Li and Lo (2015) found that the longer an online video advertisement is, the higher is the likelihood of the advertised brand being recognised. Furthermore, an online video advertisement's position affects its effectiveness. Krishnan and Sitaraman (2013) found that mid-roll advertisements have higher completion rates than pre- and post-roll advertisements as viewers are less engaged in the beginning and at the end of the video. However, mid-roll advertisements are also perceived as most intrusive as they interrupt the viewer whilst watching the video (Li and Lo 2015).

Moreover, Belanche et al. (2017) and Li and Lo (2015) analysed the effect of context congruency. Context congruence refers to the degree of similarity between the video and the advertisement content (Belanche et al. 2017). According to Weber's law, stimuli that differ from other stimuli are more likely to be noticed by consumers (Solomon 2013). It is assumed that through the more differing stimuli when using incongruent advertisements, more internal processing is activated and thus incongruent advertisements are remembered better (Feltham and Arnold 1994). In contrast, other authors argue that advertising messages within congruent contexts are more effective as the information is processed more intensely and positively and thus the congruency favourably influences the evaluation of the advertisement and attitude towards the brand (Belanche et al. 2017).

\section{Research Gap and Framework}

The tourism industry has been identified as one of the industries, which experienced the most significant changes through the emergence of social media (Xiang and Gretzel 2010). Moreover, YouTube is considered as a tool with a high potential for promotional efforts within tourism as accommodation providers and destination management offices can offer audio-visual content regarding their products and services and consumers are increasingly searching for travel-related information on YouTube (Crowel et al. 2014, Reino and Hay 2016). Therefore, this study will assess the effectiveness of YouTube advertising within the tourism industry.

Previous research of advertising effectiveness within the tourism industry focused mainly on destinations. Besides destinations, multiple other service providers such as accommodation providers, carriers, tour operators, travel agencies and meta search engines are part of the tourism industry. However, none of these stakeholders have been subject to research of online advertising effectiveness yet. This is especially surprising since hotel chains and meta search engines such as Trivago and Kayak are among the organisations with the highest online advertising expenditures and make significant use of advertising opportunities on social media with YouTube being a substantial part of their advertising strategy (eMarketer 2016a, Wordstream 2011). However, as already 
mentioned within the introduction, especially Trivago is facing low returns on advertising spend (Jhonsa 2016). Therefore, the focus of this study will be to assess the effectiveness of YouTube advertising within the tourism industry on the example of the meta search engine Trivago.

The literature review has shown that due to the information-intense nature of tourism-related products, social media has a significant role within the search stage of the consumer decision-making process (Xiang and Gretzel 2010). Travellers use social media in particular to collect information about destinations, accommodations and experiences of other consumers (Crowel et al. 2014). Hence, it has to be examined whether advertising by touristic organisations on social media is only effective, when users are already interacting with travel-related information. Therefore, also the effect of context congruence between the video and the advertisement will be assessed within this work. Figure 2 shows the framework that will be applied to analyse the effectiveness of YouTube advertising in this research.

\section{Figure 2. Research Framework}

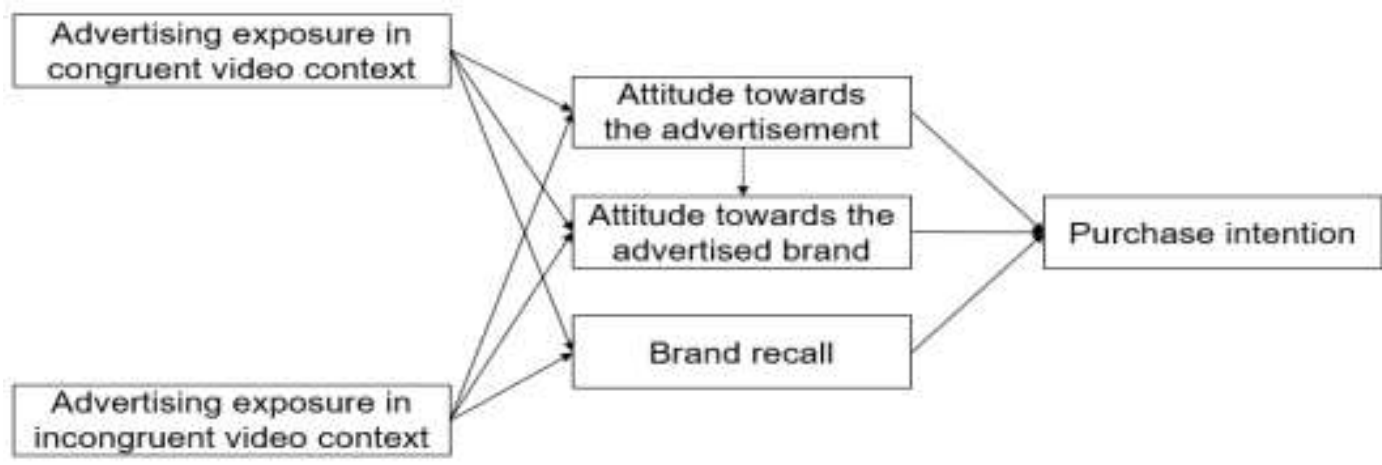

\section{Methodology}

For this research, semi-structured interviews were selected as they enable the researcher to gain in-depth insights and understanding of attitudes, opinions, processes, experiences and behaviours (Rowley 2012). The employed questions were of open, specific and probing nature. Thus, interviewees were encouraged to provide extensive answers and responses of greater significance could be explored further (Cameron and Price 2009).

The interviewee selection followed a purposive, homogenous sampling approach. Employing this approach, participants were selected based on the researcher's judgement on the participants' capacity to contribute to the research (Quinlan 2011). As a homogenous approach was chosen, all members of the sample were similar (Saunders et al. 2016). This similarity was based on several criteria. As the research was conducted in Germany, all participants were German nationals. Moreover, all participants were aged between 18 and 35 years as the majority of YouTube users is between 25 and 34 years old, followed by the age groups from 35 to 44 and 18 to 24 years (Blattberg 2015). Furthermore, interviewees needed to fulfil the criteria of having travelled at least once for 
touristic purposes in the past year and being regular internet users who are familiar with the platform YouTube. Lastly, the majority of interviewees had an academic background. The researcher knew all interviewees to different degrees on a personal level before the research. After 15 interviews, a saturation was identified and no new findings emerged. Thus, 15 interviews have been considered as appropriate for this research. Table 1 contains basic information regarding each interviewee.

As identified within the literature review, males and females are equally active on YouTube. Therefore, an equal gender split was approached when selecting the respondents. Moreover, all interviewees are active travellers. 12 respondents travel more than twice per year for touristic purposes.

\section{Selection of YouTube Videos and Advertisement}

At the beginning of the interview, participants were shown a YouTube video including a Trivago advertisement to assess the immediate effect of YouTube advertising on aspects such as brand recall and purchase intention within the interview. To investigate the effect of context congruence, interviewees were split into two groups out of which one watched a video out of context with the advertisement. The second group watched a video not in context with the advertisement. The integrated advertisement was the same within both groups. Table 2 provides an overview of the properties of the selected videos and the advertisement.

Selecting the videos, the aim was to find content that the participants would also watch if they were browsing independently on YouTube. Hence, it needed to be ensured that the content of the videos is not too specific but still engaging enough to create common interest. As Hamburg is Germany's third most visited city (DRV, 2017), it is likely that each interviewee has already visited the city or plans to travel there. Thus, a common interest was ensured. The second video was chosen as the tricks presented are universally applicable and, thus, a common interest in the video could be assumed. As previous research has shown that extreme stimuli within videos and advertisements irritate users (Belanche et al. 2017), videos with loud music and extreme visual effects were avoided. Moreover, videos branded by other touristic organisations were not chosen to prevent confusion when participants were asked to recall the brand advertised in the video. To create a natural environment and make the participants feel comfortable, the selected material was in German. As the video length affects advertising acceptance (Krishnan and Sitaraman 2013), both videos needed to be of the same length to ensure comparability. To identify two suitable videos, a total of 80 videos on YouTube was reviewed. 
Table 1. Interviewee Profiles

\begin{tabular}{|c|c|c|c|c|c|c|}
\hline Interviewee & Gender & Age & Educational background & Usage of YouTube & $\begin{array}{c}\text { Number of touristic trips in } \\
\text { past year }\end{array}$ & Booking behaviour \\
\hline $\mathrm{P} 01$ & Female & 23 & Bachelor's degree & Several times per month & More than two & Travel agency and online \\
\hline $\mathrm{P} 02$ & Female & 20 & German A levels & Daily & Two & Online \\
\hline $\mathrm{P} 03$ & Female & 24 & Bachelor's degree & Several times per week & More than two & Usually online \\
\hline $\mathrm{P} 04$ & Male & 24 & Secondary school certificate & Daily & More than two & Online \\
\hline $\mathrm{P} 05$ & Male & 27 & Master's degree & Daily & More than two & Online \\
\hline P06 & Male & 23 & Bachelor's degree & Daily & One & Travel agency and online \\
\hline P07 & Male & 25 & Bachelor's degree & Several times per week & More than two & Usually online \\
\hline $\mathrm{P} 08$ & Female & 23 & Bachelor's degree & Several times per month & More than two & Online \\
\hline P09 & Female & 25 & Bachelor's degree & Several times per week & More than two & Online \\
\hline $\mathrm{P} 10$ & Female & 25 & Bachelor's degree & Daily & More than two & Online \\
\hline $\mathrm{P} 11$ & Female & 23 & Bachelor's degree & Several times per week & More than two & Travel agency and online \\
\hline $\mathrm{P} 12$ & Male & 35 & Bachelor's degree & Daily & More than two & Online \\
\hline $\mathrm{P} 13$ & Female & 24 & Bachelor's degree & Several times per week & More than two & Travel agency and online \\
\hline $\mathrm{P} 14$ & Male & 23 & Bachelor's degree & Daily & More than two & Online \\
\hline $\mathrm{P} 15$ & Male & 18 & Secondary school certificate & Daily & One & Online \\
\hline
\end{tabular}

Table 2. Overview of Advertisement and Videos Shown to Participants

\begin{tabular}{|c|c|c|c|c|}
\hline & Title & Length & \begin{tabular}{|l|} 
Description of content \\
\end{tabular} & Accessible via \\
\hline Advertisement & $\begin{array}{l}\text { Find your ideal hotel } \\
\text { for the best rate - } \\
\text { Trivago }\end{array}$ & $\begin{array}{c}15 \\
\text { seconds }\end{array}$ & $\begin{array}{l}\text { A visible narrator demonstrates the functionalities and advantages of using Trivago to } \\
\text { book an accommodation. The Trivago logo is present throughout the entire spot in the } \\
\text { right bottom corner. At the end of the advertisement, the logo is shown in a large } \\
\text { format and Trivago's website address is given. }\end{array}$ & https://bit.ly/2rX3YBI \\
\hline Video 1 & $\begin{array}{l}\text { Declaration of love to } \\
\text { Hamburg }\end{array}$ & 2:20 minutes & $\begin{array}{l}\text { The video presents the major sights of the German city Hamburg. The video engages } \\
\text { the viewer through the usage of an appealing imagery, slowly building up background } \\
\text { music and a vivid narration. }\end{array}$ & https://bit.ly/2SbHK9K \\
\hline Video 2 & $\begin{array}{l}10 \text { brilliant tricks that } \\
\text { help you along }\end{array}$ & 2:20 minutes & $\begin{array}{l}\text { Being completely unrelated to tourism and travel, the video presents ten so-called life } \\
\text { hacks, simple tips and tricks easing the daily life. The viewer is engaged through the } \\
\text { humorous narration and by learning about the handy tricks presented. }\end{array}$ & https://bit.ly/38Vv8JG \\
\hline
\end{tabular}




\section{Findings and Discussion}

\section{Attitude towards the Tourism Advertised Brand}

All respondents knew Trivago before the interview, in particular through television and YouTube advertising. Being asked about their opinion on Trivago, the majority of respondents stated that they have a neutral opinion on the brand as they have never booked a hotel via Trivago. P05, P13 (congruent group), P04, P08 and P12 (incongruent group) felt positive about Trivago as they consider it a useful and handy service to compare prices.

Furthermore, the interviewees were asked whether watching the advertisement changed anything about their opinion on Trivago to identify whether there is a relationship between the attitude towards the advertisement and the attitude towards the brand. Within the congruent group, this was negated by all respondents. Except for P13, who felt more positive about the brand after having seen the advertisement. Within the answers of five respondents, no relationship between the attitude towards the advertisement and advertised brand could be identified. However, among two respondents it was observed that the negative perception of the advertisement affected the attitude towards the brand and also the purchase intention negatively. P02 and P11 stated that they will not book a hotel via Trivago as they felt too disturbed and not appealed by the advertisement. These answers represented a contradiction to P02's and P11's previous statement that the advertisement did not change anything about their opinion of the brand. This partially supports Truong and Simmons (2010) who found that negatively perceived online advertisement can lead to a negative view of the advertised brand and that there is a relationship between the processing of the advertisement and the attitude towards the brand as identified by Metha (1994) and Hwang et al. (2011).

Within the incongruent group, all respondents besides P08 and P12 stated that watching the advertisement did not change their opinion on Trivago in a positive or negative way. Only P08 and P12 stated that they feel more likely to now consider Trivago through the constant repetition of the advertisement and as the advantages were well explained within the advertisement.

Being asked how the brands employing online advertising are perceived, the majority of respondents from both groups answered that they usually cannot remember, do not notice or just ignore the advertisements and thus the advertising brand. Because of the lack of conscious advertising processing due to these avoidance behaviours, no attitude towards the advertising brand is developed.

\section{Factors Influencing the Effectiveness of YouTube Advertising in Tourism}

The effect of the advertisement on the respondents' purchase intention was explored. Within the congruent group, P02, P07, P10 and P11 negated that they will book a hotel via Trivago in the future. Whereas for P02 and P11 the reason was the high degree of annoyance caused by the advertisement, P07 and P10 argued that they are also not more likely to book via Trivago as they do not depend on a certain brand or website and have already booking patterns which they will 
not change due to advertisements. In contrast, P03 and P05 stated that they might consider Trivago if it is the cheapest option but acknowledged that the choice of the booking platform would only depend on the price and not be a consequence of the exposure to the advertisement. However, P05 confirmed that due to the continuous exposure to the brand through advertising, the familiarity and thus also the likelihood to check the website increases.

Within the incongruent group, P08 and P12 confirmed that they are more likely to book via Trivago in the future. The remaining interviewees declared that they are not more likely to book via Trivago for various reasons. P01, P14 and P15 shared the opinion that the advertisement has no influence on them. P04, P06 and P09 have already different ways to book their hotels via platforms such as booking.com or directly on the website of the hotel.

In line with the findings regarding the attitude towards the brand, the advertisement failed to influence the purchase intention positively amongst individuals who did not already have a positive attitude towards the brand. However, it has to be acknowledged that there might be delayed effects of the advertisement and although they are currently denying it, interviewees will book via the website in the future due to the exposure to the advertisement.

Except for one, all respondents agreed that it makes a difference where the advertisement is placed. Advertisements positioned at the beginning are tolerated by most respondents as it is expected and familiar that there will be advertising in this place, also from other channels such as TV or cinema. However, several respondents stated that they skip these advertisements as soon as possible as they are eager to watch the video.

Advertisements placed in the middle are considered as particularly annoying and disturbing by most respondents. At the same time, P04 and P09 acknowledged that they are most likely to watch mid-roll advertisements as they want to know how the video continues. These statements support the finding of Krishnan and Sitaraman (2013) that mid-roll advertisements have the highest completion rates. However, P08 explained that if the video has not caught sufficient interest, the appearance of a mid-roll advertisement can be a reason for her to leave the entire video. The most preferred form of all respondents are post-roll advertisements as these can either be skipped to continue with the next video or can be avoided by just putting for example the phone away or closing YouTube. This is further evidenced by Krishnan's and Sitaraman's (2013) finding that post-roll advertisements have the lowest completion rates.

As Krishnan and Sitaraman (2013) argued that advertisements placed in longer videos have higher completion rates than those placed in short videos, interviewees were also asked whether they mind advertisements less if the videos are longer than five minutes. This was partially confirmed as six respondents agreed that they mind the advertisements less in longer videos since they have to invest more time to complete the video anyway and that advertisements are expected in longer videos, comparable with TV. However, the remaining respondents stated that the video length does not make any difference. Instead, P06, P09 and P10 indicated that the advertisement's position has a more significant effect on their advertisement acceptance than the length of the video. 


\section{Use of YouTube for Tourism Industry}

To investigate the role of YouTube for the tourism industry, participants were asked how they use YouTube in relation to travelling. Six respondents confirmed that they have already used YouTube to search for information before going on a trip. The searched information included the major sights, excursion tips, local specialities, experience reports of people who already travelled to the destination and directions. All six respondents concurred that YouTube offers extensive information and that they found everything they were looking for. Nevertheless, the majority of nine respondents stated that they have not used YouTube for information search yet. The main reason given was that there was no awareness that information such as an overview of the top sights is provided on YouTube.

P1 argued that she prefers text-based websites as it is easier to find immediately what is needed and that the search on YouTube is more complicated than on search engines such as Google. P05 added that looking for information on YouTube is quite time-consuming whereas a search initiated via Google is faster. Moreover, P07 stated that he perceives videos as too superficial and, thus, prefers text-based information. However, none of the respondents who do not use YouTube for information search has any other specific websites they prefer for information search. Their search processes start usually with a general search on Google. Except for P01, P05 and P07, the remaining respondents who do not use YouTube yet sympathised with the idea of using YouTube in the future. These findings confirm the importance of social media channels such as YouTube for information search within the tourism industry as previously identified by Xiang and Gretzel (2010). Moreover, the answers indicate a tremendous future potential for organisations within the tourism industry to provide users with specialised content regarding destinations via YouTube.

\section{Conclusion}

The exposure to the tourism advertisement resulted in successful brand and advertisement recall. However, in terms of the attitude towards the tourism advertised brand and purchase intention, no particularly positive effect could be identified. Although the advertisement recall was greater in the incongruent group, no significant observations could be made in regards to the differences between the two groups. This is mainly due to the fact that the perception of congruence is highly subjective and cannot be judged by third parties. However, it needs to be noticed that this analysis refers only to the immediate effects of the exposure to the advertisement. One of the major problems in assessing tourism advertising effectiveness is that the effects might occur delayed, for example, a purchase is made after weeks of exposure to the advertisement (Moriarty et al. 2014). Supportive to this notion is that several respondents acknowledged that through the constant repetition of the advertisement, the familiarity with the brand increases which might also increase the likelihood that a purchase via Trivago is made. 
The interviews were used to analyse whether negative effects are related to the exposure to YouTube advertising within the tourism industry. No immediate negative effects were observed among the residual respondents. Instead of changing their attitude towards the brand, the majority of respondents kept a neutral opinion of the brand. Thus, no significant positive but also no negative effects of the exposure to YouTube advertising in regards to the attitude towards the brand could be identified.

However, it was stated by several respondents that the repetitive exposure to the same Trivago advertisement on YouTube and across other channels leads to feelings of annoyance and tedium. Additionally, several avoidance behaviours were described by respondents. With the appearance of an advertisement, participants often open, for example, another tab, check their phone or just look away to avoid the exposure to the advertisement. According to Smith (2012) and Truong and Simmons (2010), reasons for these reactions can be the overuse of advertisements and an overly high degree of intrusiveness. Thus, it can be concluded that the exposure to YouTube advertising per se does not have negative effects but the way it is executed can lead to negative reactions. Therefore, the degree of intrusiveness should be reduced to decrease avoidance behaviours and achieve more active advertisement processing. Investigating the factors influencing the effectiveness, it was identified that mid-roll advertisements are perceived as most annoying and disturbing. In order to decrease the degree of intrusiveness, advertisement types such as mid-roll advertisements should rather be avoided and instead, for example, pre-roll advertisements used. Additionally, varying tourism advertisements should be employed as the research showed that respondents are more likely to watch an advertisement if it is something interesting they have not seen before. This suggests also that advertisements used for television should not be used on YouTube to reduce the repetitive exposure to the same advertisements.

The research objective requires recommendations whether the use it was found that due to its high intrusiveness, YouTube advertising is a suitable channel to create tourism brand awareness and also to keep the brand in the customer's mind. However, the research has shown that in regards to tourism advertising objectives such as building brand preference or persuading consumers to purchase, YouTube is not the ideal channel. Findings confirmed that as the user has a specific objective when watching a video, there is no willingness to purchase when processing content on YouTube. Instead, Facebook was identified as a more suitable channel when it comes to persuading customers to buy. However, it was also noticed that the products the interviewees bought via Facebook were predominantly low-involvement products such as make-up, phone covers or books. Due to their higher cost, products related to travelling can be considered as high-involvement products as a higher financial risk is involved for the consumer (Leung et al. 2013). Thus, it can be assumed that impulse purchases on Facebook as described by the respondents, do not occur in regards to tourism-related products because of the higher involvement required. Therefore, it can be concluded that the effectiveness of YouTube advertising depends on an organisation's specific advertising objectives. It can also be questioned whether 
online advertising is in general suitable for the achievement of persuasive advertising objectives within the tourism industry due to the high involvement required when purchasing the products.

Furthermore, the research has revealed YouTube's significant potential for information search within the tourism industry. It is, therefore, recommended that touristic organisations such as Trivago make more use of the opportunity to provide branded content on YouTube by uploading videos containing, for example, tips for a destination's top accommodations and clearly visualise the logo of the brand within these videos. Especially for organisations with smaller advertising budgets, this would represent a suitable alternative to the costly advertising.

Previous studies did not assess the suitability of YouTube advertising for a specific industry. Due to the significance of social media for the tourism industry, the industry's high overall expenditures on advertising and YouTube's growing importance for the search of travel-related information, this study is the first which investigated the effectiveness of YouTube advertising in the context of the tourism industry.

As platforms such as Instagram and Snapchat are increasingly offering opportunities for online video advertising, this research should be replicated with a focus on these platforms. Conducting a cross-comparison with the findings of this research would enable tourism marketers to gain a more comprehensive picture of the strengths and opportunities of each platform and provide them with a better understanding on how to allocate budgets in order to maximise advertising effectiveness.

\section{References}

Ayeh JK, Au N, Law R (2013) "Do we believe in TripAdvisor?" Examining credibility perceptions and online travellers' attitude toward using user-generated content. Journal of Travel Research 52(4): 437-452.

Belanche D, Flavian C, Perez-Rueda A (2017) Understanding interactive online advertising: congruence and product involvement in highly and lowly arousing, skippable video ads. Journal of Interactive Marketing 37(Feb): 75-88.

Blattberg E (2015) The demographics of YouTube, in 5 charts. Retrieved from: http://digiday.com/media/demographics-youtube-5-charts/.

Broussard G (2000) How advertising frequency can work to build online advertising effectiveness. International Journal of Market Research 42(4): 439-457.

Calder BJ, Malthouse EC, Schaedel U (2009) An experimental study of the relationship between online engagement and advertising effectiveness. Journal of Interactive Marketing 23(4): 321-331.

Cameron S, Price D (2009) Business research methods: a practical approach. London: Chartered Institute of Personnel and Development.

Chandon JL, Chtourou MS, Fortin DR (2003) Effects of configuration and exposure levels on responses to web advertisements. Journal of Advertising Research 43(2): 217229.

Chatterjee P (2001) Beyond CPMs and clickthroughs: consumer interaction with web advertising. Internet Marketing Research: Theory and Practice (Jun): 209-216. 
Cox C, Burgess S, Sellitto C, Buultjens J (2009) The role of user-generated content in tourists' travel planning behavior. Journal of Hospitality Marketing \& Management 18(8): 743-764.

Crowel H, Gribben H, Loo J (2014) Travel content takes off on YouTube. Think with Google. Retrieved from: https://www.thinkwithgoogle.com/consumer-insights/travelcontent-takes-off-on-youtube/.

Dehghani M, Niaki MK, Ramezani I, Sali R (2016) Evaluating the influence of YouTube advertising for attraction of young customers. Computers in Human Behavior 59(Jun): 165-172.

Drèze X, Hussherr FX (2003) Internet advertising: is anybody watching? Journal of interactive marketing 17(4): 8-23.

DRV - Deutscher Reiseverband (2017) Fakten und Zahlen zum Reisemarkt. (Facts and figures about the travel market). Retrieved from: https://www.drv.de/fachthemen/ statistik-und-marktforschung/fak ten-und-zahlen-zum-reisemarkt.html. [Accessed 8 July 2017].

eMarketer (2016a). Digital video advertising continues to expand. Retrieved from: https://www.emarketer.com/Article/Digital-Video-Advertising-Continues-Expa $\mathrm{nd} / 1013722$.

Faith C (2014). The top industries spending the most on AdWords and why. Smartsites Blog. Retrieved from: http://www.smartsites.com/blog/top-industries-spendingadwords/.

Fotis J, Buhalis D, Rossides N (2012) Social media use and impact during the holiday travel planning process. In M Fuchs, F Ricci, L Cantoni (Eds), 13-24. Information and Communication Technologies in Tourism 2012. Vienna: Springer-Verlag.

Huang J, Su S, Zhou L, Liu X (2013) Attitude toward the viral ad: expanding traditional advertising models to interactive advertising. Journal of Interactive Marketing 27(1): $36-46$.

Hudson S, Thal K (2013) The impact of social media on the consumer decision process: implications for tourism marketing. Journal of Travel \& Tourism Marketing 30(1-2): 156-160.

Hwang J, Yoon YS, Park NH (2011) Structural effects of cognitive and affective responses to web advertisements, website and brand attitudes, and purchase intentions: the case of casual-dining restaurants. International Journal of Hospitality Management 30(4): 897-907.

Ibrahim M (2013). Digital marketing is "invasive and annoying", study claims. Campaignlive. Retrieved from: http://www.campaignlive.co.uk/article/digitalmarketing-invasive-annoying-study-claims/1185778.

Jhonsa E (2016) Trivago's eye-popping advertising spend might be responsible for its uninspiring IPO. Retrieved from: https://www.thestreet.com/story/ 13929348/2/trivago-s-eye-popping-advertising-spend-might-be-responsible-for-itsuninspiring-ipo.html.

Kotler P, Armstrong G (2016) Principles of marketing. $16^{\text {th }}$ Edition. Harlow: Pearson Education Limited.

Krishnan SS, Sitaraman RK (2013) Understanding the effectiveness of video ads: a measurement study. In Proceedings of the 2013 conference on internet measurement, 149-162. Retrieved from: http://dl.acm.org/ citation.cfm?id=2504748. [Accessed 10 February 2017].

Lavrakas PJ, Mane S, Laszlo J (2010) Does anyone really know if online ad campaigns are working? Journal of Advertising Research 50(4): 354-373.

Lee J, Lee H (2012) Canonical correlation analysis of online video advertising viewing motivations and access characteristics. New Media \& Society 14(8): 1358-1374. 
LePage E (2016). All the social media advertising stats you need to know. Hootsuite Blog. Retrieved from: https://blog.hootsuite.com/social-media-advertising-stats/.

Leung D, Law R, Van Hoof H, Buhalis D (2013) Social media in tourism and hospitality: a literature review. Journal of Travel \& Tourism Marketing 30(1-2): pp. 3-22.

Li H, Lo HY (2015) Do you recognize its brand? The effectiveness of online in-stream video advertisements. Journal of Advertising 44(3): 208-218.

Manap KA, Adzharudin NA (2013) The role of user generated content (UGC) in social media for tourism sector. In The 2013 WEI International Academic Conference Proceedings, 52-58. Retrieved from: https://pdfs.semanticscholar.org/8b03/c9 ca4d8238938629d9afc0e1245067f118bc.pdf. [Accessed 3 June 2017].

Martín-Santana JD, Beerli-Palacio A (2012) The effectiveness of web ads: rectangle vs contextual banners. Online Information Review 36(3): 420-441.

Metha A (1994) How advertising response modelling (ARM) can increase ad effectiveness. Journal of Advertising Research 34(3): 62-62.

Miller M (2011) YouTube for business: online video marketing for any business. $2^{\text {nd }}$ Edition. Indianapolis, Ind.: Que.

Moriarty S, Mitchell ND, Wells WD, Crawford R, Brennan L, Spence-Stone R (2014) Advertising: principles and practice. Australia: Pearson.

Nielsen (2016). The latest YouTube stats on audience demographics: who's turning in. Retrieved from: https://www.thinkwithgoogle.com/data-collectio ns/youtube-viewerbehavior-online-video-audience/. [Accessed 20 February 2017].

Pavlou P, Stewart D (2000) Measuring the effects and effectiveness of interactive advertising. Journal of Interactive Advertising 1(1): 61-77.

Pratt S, McCabe S, Cortes-Jimenez I, Blake A (2010) Measuring the effectiveness of destination marketing campaigns: Comparative analysis of conversion studies. Journal of Travel Research 49(2): 179-190.

Quinlan C (2011) Business research methods. Andover: Cengage Learning.

Reino D, Hay B (2016) The use of YouTube as a tourism marketing tool. Retrieved from: http://scholarworks.umass.edu/ttra/2011/Visual/69/. [Accessed 4 June 2017].

Robinson H, Wysocka A, Hand C (2007) Internet advertising effectiveness: the effect of design on click-through rates for banner ads. International Journal of Advertising 4(Jun): 527-541.

Rohrs J (2014) Audience marketing in the age of subscribers, fans \& followers. Hoboken: Wiley.

Rosenkrans G (2009) The creativeness and effectiveness of online interactive rich media advertising. Journal of Interactive Advertising 9(2): 18-31.

Rowley J (2012) Conducting research interviews. Management Research Review 35 (34): $260-271$.

Shani A, Chen PJ, Wang Y, Hua N (2010) Testing the impact of a promotional video on destination image change: application of China as a tourism destination. International Journal of Tourism Research 12(2): 116-133.

Shields M (2016) YouTube's quest for TV advertising dollars. The Wall Street Journal. Retrieved from: https://www.wsj.com/articles/youtubes-quest-for-tv-advertisingdollars-1461343177.

Smith K (2012) Longitudinal study of digital marketing strategies targeting Millennials. Journal of Consumer Marketing 29(2): 86-92.

Solomon MR (2013) Consumer behavior: buying, having and being. $10^{\text {th }}$ Edition. Upper Saddle River New York: Pearson Prentice Hall.

Statista (2016) Leading countries based on number of monthly active YouTube users as of $1^{\text {st }}$ quarter 2016. Retrieved from https://www.statista.com/statis tics/280685/numberof-monthly-unique-youtube-users/. [Accessed 10 February 2017]. 
Wordstream (2011) What industries contributed the most to Google's earnings? Retrieved from http://www.wordstream.com/articles/google-earnings. [Accessed 14 May 2017].

Xiang Z, Gretzel U (2010) Role of social media in online travel information search. Tourism management 31(2): 179-188.

YouTube (2012) YouTube in-stream ads. Retrieved from: https://static.goo gleusercontent.com/media/www.youtube.com/en//yt/advertise/medias/pdfs/instreamonesheeter-en.pdf. [Accessed 14 May 14 2017].

YouTube (2017) YouTube for press. Retrieved from https://www.youtu be.com/intl/enGB/yt/about/press/. [Accessed 5 August 2017].

Zeng B, Gerritsen R (2014) What do we know about social media in tourism? A review. Tourism Management Perspectives 10(Apr): 27-36. 